\title{
The Papacy, Power, and Print: The Publication of Papal Decrees in the First Fifty Years of Printing
}

\author{
Margaret Meserve
}

Historians of early modern Europe have long remarked on the closely intertwined histories of printing and the Reformation. ${ }^{1}$ Recent studies have cast new light on just how the new technology of print was adopted by the Reformers and contributed to the rapid spread of Luther's challenge to papal authority. ${ }^{2}$ The picture that emerges is that of an enterprising group of theologians and scholars working in collaboration with equally enterprising printers to spread a revolutionary message to the European reading public. Using cheap formats like the broadside or the quarto pamphlet, publishing texts in both the high scholastic Latin of academic theology and in local vernaculars, and relying on images as well as text to convey their key points, Reformers and printers worked together to launch a momentous religious and social movement. Meanwhile, conventional wisdom has it, the papacy, the conservative and authoritarian institution on the receiving end of these printed critiques, stood by, unsure how to respond or unwilling to seize the same tools and engage in the same popularising discourse.

This somewhat simplistic account (which I admit I have further simplified here) overlooks the fact that at the start of the sixteenth century, the Roman Catholic Church presided over the largest and most elaborate communication apparatus in the western world. ${ }^{3}$ The pope claimed spiritual jurisdiction over every Latin-rite Christian from Iceland to the Middle East and beyond; for

1 Lucien Febvre and Henri-Jean Martin, David Gerard (trans.), The Coming of the Book. The Impact of Printing 1450-1800 (London: N.L.B., 1976), pp. 287-319; Elizabeth Eisenstein, The Printing Press as an Agent of Change: Communications and cultural transformations in Early-Modern Europe (Cambridge: Cambridge University Press, 1980); Robert Scribner, For the Sake of Simple Folk: Popular Propaganda for the German Reformation (Cambridge: Cambridge University Press, 1981); Stephan Füssel, Douglas Martin (trans.), Gutenberg and the Impact of Printing (Aldershot: Ashgate, 2005), pp. 159-194.

2 Andrew Pettegree, Reformation and the Culture of Persuasion (Cambridge: Cambridge University Press, 2005) and his Brand Luther: 1517, Printing, and the Making of the Reformation (London: Penguin Press, 2015).

3 For a comparison with medieval China, see Patricia Ebrey and Margaret Meserve, 'Giving the Public Due Notice in Song China and Renaissance Rome', in Hilde De Weerdt and 
centuries, the papal chancery had been issuing documents (bulls, briefs, pardons, dispensations, confessional certificates, indulgences, and the like) to these far-flung communities. ${ }^{4}$ Arguably it was the ubiquity of papal documents (and the economy of grace and pardon that brought them into being and which they in turn allowed to flourish) that prompted Luther to formulate his new theology in the first place.

The Church's communication system had expanded to exploit the new technology of printing from almost the very moment of its invention. The substantial but little-studied archive of early papal print, which is the subject of this article, is surprising for both its variety and its scale, and reveals that the late medieval Church, despite its conservative and authoritarian tendencies, was entirely ready to adopt the new technology of mass communication. ${ }^{5}$ Nevertheless, the uneven way in which the new medium was used in its early years reveals something of the priorities and prejudices of the popes and their chancery officials in Rome, on the one hand, and those of papal commissioners or local clergy at work on the ground across the continent, on the other.

The Roman centre was slower to adopt print than was the European periphery. However, after a few decades of relatively sparse production, papal use of the press rose dramatically during the energetic and aggressive reign of Pope Julius II (1503-1513) and continued under his successor, Leo X (1513-1521), author of the first bulls to condemn Luther's theses and eventually, the pope who excommunicated him. During their two pontificates, dozens of papal bulls, briefs, monitoria, and other decrees were put into print by presses in Rome as well as abroad, in Latin but also in German, French, and Italian, often deploying a striking and innovative graphic as well as textual vocabulary. Thus there was plenty of papal print before the Reformation, and plenty of it after 1517, as well. How much of it was effective is another question. The story of the Renaissance papacy's energetic use of the press has intriguing implications

Franz-Julius Morche (eds.), Political Communication in Chinese and European History, 80o-160o (Amsterdam: Amsterdam University Press, 2021), pp. 345-386.

4 For the workings of the medieval chancery see Thomas Frenz, I documenti pontifici nel medioevo e nell'eta moderna (Vatican City: Scuola Vaticana di paleografia, diplomatica e archivista, 1989); for its geographical reach: Gerhard Jaritz, Torstein Jørgensen, and Kirsi Salonen (eds.), The Long Arm of Papal Authority: Late Medieval Christian Peripheries and their Communication with the Holy See (Bergen/Budapest/Krems: Central European University Press, 2004); Kirsi Salonen and Ludwig Schmugge, A Sip from the "Well of Grace": Medieval Texts from the Apostolic Penitentiary (Washington DC: The Catholic University of America Press, 2009).

5 The topics sketched in this article are treated in more detail in Margaret Meserve, Papal Bull: Print, Politics, and Propaganda in Renaissance Rome (Baltimore: Johns Hopkins University Press, 2021). 
for the larger history of communications technology. It may be that it was not their command of print that gave the Reformers their early advantage over Rome so much as a genuinely more persuasive rhetoric: that it was the message, not the medium, after all.

\section{Papal Printing in the Fifteenth Century}

The papacy was involved with the art of printing - albeit in an oblique way from its earliest days. As Gutenberg brought the great work of his Bible to completion in the mid-145os in Mainz, his shop had already started producing smaller works, possibly as a way of experimenting with and refining Gutenberg's new technique. These ephemeral pieces included two indulgences issued by Pope Nicholas V in 1454 for members of the faithful who contributed funds to a new crusade against the Turks, who had conquered Constantinople the previous year. ${ }^{6}$ These were followed, in $145^{6}$, by a bull of Calixtus III encouraging further contributions to the crusade, a text which appeared in print in both Latin and in a German translation. ${ }^{7}$ In 1459 , the archbishopric of Mainz fell vacant, and two candidates vied for the position: one backed by Pope Pius II and one supported by the cathedral chapter and city. Each side used the press to publish letters supporting their claims and attacking the other candidate, including some seven bulls and briefs issued in the name of Pius II and printed by Gutenberg's partners in Mainz, Johann Fust and Peter Schoeffer. ${ }^{8}$ That

6 For the attribution of these unsigned early pieces to Gutenberg, who may have been operating two separate shops in Mainz, one with Johann Fust and one on his own: see Janet Ing Freeman and Paul Needham, Johann Gutenberg and his Bible: An Historical Study (New York: The Typophiles, 1988), pp. 62-65 and Füssel, Gutenberg and the Impact of Printing, pp. 25-29.

7 In this article I use ISTC numbers for incunabula and USTC numbers for items printed after 150o. The 30 -line indulgence using the type of the 42 -line Bible: icoo42240o; the 31 -line indulgence using the type of the 36 -line Bible: icoo4226oo; Calixtus' Bulla Thurcorum: icooo6oooo (Latin) and icooo6o10o (German). See George Painter, 'Gutenberg and the B36 Group: A Reconsideration', in Dennis Rhodes (eds.), Essays in Honor of Victor Scholderer (Mainz: Karl Pressler Verlag, 1970), pp. 292-322; Janet Ing, 'The Mainz Indulgences of 1454/5: A Review of Recent Scholarship', British Library Journal, 9 (1983), pp. 14-31; Blaise Agüera y Arcas, 'Temporary Matrices and Elemental Punches in Gutenberg's DK type', in Kristian Jensen (ed.), Incunabula and Their Readers: Printing, Selling, and Using Books in the Fifteenth Century (London: British Library, 2003), pp. 1-12; Joseph A. Dane, Out of Sorts: On Typography and Print Culture (Philadelphia: University of Pennsylvania Press, 2011), pp. $3^{2-56 .}$

8 Kai-Michael Sprenger, 'Die Mainzer Stiftsfehde 1459-1463', in Michael Matheus (ed.), Lebenswelten Gutenbergs (Stuttgart: Steiner, 2000), pp. 107-141; Christian von Heusinger, 'Die Einblattdrucke Adolfs von Nassau zur Mainzer Stiftsfehde', Gutenberg Jahrbuch, (1962), pp. 341-352; Konrad Repgen, 'Antimanifest und Kriegsmanifest. Die Benutzung der neuen 
dispute eventually led to violent conflict in the city of Mainz, which prompted many of the city's early printers to flee in search of other markets. Their number included many of the German printers who went on to set up shop in the city of Rome in the 1460 s and 147 os. $^{9}$

Papal bulls were thus some of the earliest texts to be printed, and their publication was closely bound up with contemporary political crises, both local and international; but no one could claim that Nicholas v or Calixtus III or Pius II commissioned or even knew that these documents were being printed in their name in the distant Rhineland. Enterprising local clerics and commissioners surely deserve the credit for their publication. Even after German printers brought the art of printing to Rome in the late 146os, the papal curia only adopted the new technology in fits and starts. In the earliest years, there is little evidence that the popes or papal officials saw print as a tool of politics, polemics, or propaganda. But they did learn quickly.

What follows is a brief survey of papal printing drawn from the most comprehensive bibliographical databases including ISTC and USTC. A few preliminary comments are in order. Traditional cataloguing conventions will assign a wide variety of texts to a particular pope, naming him as the author of almost any document issued by the papal chancery during his reign. Pope Sixtus IV, for example, appears in ISTC as the author of some 351 editions printed during his lifetime, a tally that includes not only printed bulls conveying his decrees and pronouncements, but also indulgences issued in his name, books of chancery rules and regulations issued at the start of his pontificate, and even theological tracts that he wrote while a cardinal, well before his election to the papacy. ${ }^{10}$

Even papal bulls, despite being issued by the pope and sealed with lead and stamped with his private seal, may have been entrusted to print by different

Drucktechnik bei der Mainzer Stiftsfehde 1461/63 durch die Erzbischöfe Adolf von Nassau und Diether von Isenburg, in Johannes Helmrath, Heribert Müller and Helmut Wolff (eds.), Studien zum 15. Jahrhundert. Festschrift für Erich Meuthen (Munich: OldenbourgVerlag, 1994), pp. 781-8o3.

9 For early German printers in Rome: Alfred W. Pollard in Catalogue of Books Printed in the XVth Century now in the British Museum, Part IV (London: British Museum, 1916), pp. vii-xvi; Anna Modigliani, 'Tipografi a Roma, 1467-1477', in Massimo Miglio and Orietta Rossini (eds.), Gutenberg e Roma: Le origini della stampa nella città dei papi (1467-1477) (Naples: Electa, 1997), pp. 41-67; Arnold Esch, 'La prima generazione dei tipografi tedeschi a Roma (1465-1480): nuovi dati dai registri di Paolo II e Sisto IV', Bulletino dell'stituto storico italiano per il medio evo, 109 (2007), pp. 401-418; Arnold Esch, 'I prototipografi tedeschi a Roma e a Subiaco', in Subiaco: la culla della stampa. Atti dei convengi (Subiaco: Iter Edizioni, 2010), pp. 53-62.

10 I.e., Sixtus IV, De futuris contingentibus and De sanguine Christi et de potentia Dei, both printed in Rome by Giovanni Filippo de Lignamine in the early 1470 s and the latter reprinted in Nuremberg by Friedrich Creussner in 1473: isoo56050o, isoo579ooo, isoo 580000 . 
entities. We know, in a few cases, that the pope directly ordered or at least commented on the printing of a bull; in other cases, it will have been the papal chancery that commissioned printing as part of its routine practice of publicizing certain initiatives: the many printed editions of bulls announcing the Jubilees of 1475 and 1500 would be examples of this sort.

On the other hand, a bull conferring privileges or indulgences on a church somewhere north of the Alps would almost certainly have been printed, locally, on the orders of the clergy associated with that church. Bulls announcing new indulgences, appointing local sellers of indulgences, or endorsing their campaigns were likewise put into print on the orders of local papal commissioners; dozens of documents connected to indulgence campaigns were printed across northern Europe, while exceptionally few were printed in Rome itself. In this article I am not interested in all papal documents put into print but rather with the papacy's intentional use of the press, evidence for which includes papal documents put into print on the orders of the pope himself (where this can be discerned); papal documents put into print in Rome and thus almost certainly on the orders of the papal chancery; and papal documents put into print elsewhere that reflect the pope's immediate political priorities. This last category includes documents issued in response to political events: for example, bulls of excommunication or interdict against opponents of the papacy; bulls stripping prominent clerical critics of their offices; bulls conveying threats of diplomatic sanctions or war against rival states; and bulls condemning theological opponents of the pope as schismatic or even heretical.

If we look at tallies from individual pontificates, some distinct patterns come into view. Printing came to Rome during the reign of Paul II (1464-1471), but his chancery seems to have patronised printers infrequently and then, mostly for everyday needs. Several editions of chancery rules, ordinances, and constitutions issued by Paul II were put into print by Roman presses, and his 1470 bull announcing the 1475 Jubilee was printed seven times in the papal city.

His successor, Sixtus IV (1471-1484), also saw several editions of his administrative rules and procedures published by Roman printers (some 27 editions of these manuals and collections of procedural advice were printed over the course of his reign), as well as three bulls concerning the 1475 Jubilee, six concerning his refoundation of the Ospedale Santo Spirito in the Borgo in 1478, and some seven bulls and indulgences encouraging contributions to the crusade against the Turks.11

11 All told, $5^{1}$ editions of Sistine texts were printed in Rome during his reign. In addition to those listed above, there was one edition of a privilege for the church at Nördlingen, in Bavaria, which was also printed north of the Alps, and another eight "political" bulls and briefs, which are discussed below. One must be careful in assigning agency for the 
The situation was markedly different abroad. Only a few of Paul II's documents were published in cities outside Rome, but several hundred bulls, indulgences, constitutions, and briefs were published outside Rome in Sixtus' name - in Germany, the Low Countries, northern Italy, England, and Spain. ${ }^{12}$ We have records of some 231 editions of Sistine texts printed outside Rome, the vast majority of them printed in German lands. ${ }^{13}$ To be sure, printing had spread widely in lands north of the Alps in these decades, so the high numbers represent the work of many print shops in many cities.

Sistine texts printed outside of Rome consist almost entirely of documents of local interest such as bulls and indulgences conferring privileges upon or indulgences to specific churches or convents, or bulls confirming the election or appointment of local church officials; or indulgences sold for the benefit of faithful souls and to fund the crusade against the Turks. Printing in support of the crusade reached a peak in the later years of Sixtus' pontificate. In 1480, an Ottoman army sacked Otranto in southern Italy and occupied its surrounding territory for more than a year, while the Ottoman navy besieged the Knights of St. John on Rhodes at almost the same time. ${ }^{14}$ On Sixtus' orders, an energetic corps of mendicant indulgence preachers fanned out across Europe to promote and sell indulgences to raise funds for a new expedition against the Turks. Many of these officials turned to local printers to mass-produce not just the slips of paper bearing the text of the indulgence itself, but also various papal bulls and other documents confirming their credentials and advertising the spiritual benefits they had to offer. ${ }^{15}$

With the death of Mehmed II in the summer of 1481, the Turkish crisis seemed to subside, and the appearance of papal bulls in print declined as well. The reigns of Innocent VIII (1484-1492) and Alexander VI (1492-1503) saw modest, but steady production. Innocent's publications printed in Rome consist almost exclusively of administrative handbooks, regulations and rules (some 54 editions in total). Beyond Rome, production followed the same pattern as under Sixtus: most titles were printed in Germany, and a great many

printing of these documents. All were issued by the papal chancery, but evidence that their printing was explicitly commissioned by chancery officials can only be assumed.

12 These include one edition of Paul II's chancery rules, one edition of his 1470 Jubilee bull, and two editions of a bull concerning a feast instituted in the province of Mainz.

13 Other Italian cities account for eleven of these editions; the Low Countries, ten; England, seven, Spain, fourteen, and the German-speaking lands, 189.

14 Kenneth M. Setton, The Papacy and the Levant (1204-1571). Volume II: The Fifteenth Century (Philadelphia: The American Philosophical Society, 1978), pp. 346-380.

15 Norman Housley, 'Indulgences for crusading, 1417-1517', in Robert Norman Swanson, (ed.), Promissory Notes on the Treasury of Merits: Indulgences in Late Medieval Europe (Leiden: Brill, 2006), pp. 277-307. 
of them were either indulgences or texts promoting indulgences and the crusade against the Turks. A smaller number of bulls and briefs awarded privileges to or advertised indulgences available at particular churches, and a handful of German-language publications offered dispensations from fasting during Lent - the delightfully titled Butterbriefe. In the course of Innocent's (admittedly shorter) reign, only 134 editions appeared outside of Rome, compared to 231 under Sixtus IV. Even fewer texts were published in the name of Alexander VI (1492-1501): only 34 outside of Rome (almost all having to do with the crusade, the issue of new indulgences, and the announcement of the 1500 Jubilee), and another 25 in the city, almost all Regulae cancellariae and other administrative publications, or further announcements of and provisions for the Jubilee.

The chart below summarizes this data: editions printed in the name of each pope, published beyond Rome (orbi) in northern Italy, Spain, or countries north of the Alps (by local bishops, legates, and commissaries), as well as in Rome (urbi) and presumably on orders from or with the permission of the papal chancery. Almost every text printed outside Rome was concerned in one way or another with indulgences and dispensations on offer to the faithful, while the far smaller output produced within the city consisted mostly of manuals of regulations and rules for curialists and bulls having to do with the Jubilee. With a few exceptions (discussed in more detail below) hardly any texts printed before 1500 treated the issues perhaps most famously associated with the Renaissance papacy: few decrees concerning wars and or diplomatic disputes, dynastic politics, or cultural patronage, for example.

We might conclude, then, that the papacy certainly used the press in the fifteenth century, but not in a particularly original or interesting way: printers published books of rules and regulations for the papal bureaucracy in Rome, on the one hand, and pardons and graces for sale abroad, on the other. Beyond the sheer scale of the indulgence enterprise, there is not much that could be considered 'revolutionary' about these outputs. So when did the papacy begin to use the press as a tool of political communication? The answer lies in the final column of the chart. During the reign of Julius II (1503-1513), the number of papal documents printed in Rome (presumably, on curial orders) began not only to rise again but also to outstrip the number of documents published abroad in the name of the pope (i.e., documents published in other cities by other agents). ${ }^{16}$

16 Enumerating the production of Julian bulls, briefs, and legal publications is more difficult than for popes who reigned in the incunabular period. I derive my figures here from records in USTC, EDIT-16, the online catalogues of the Bayerische Staatsbibliothek and 
TABLE 12.1 Editions produced by the papacy

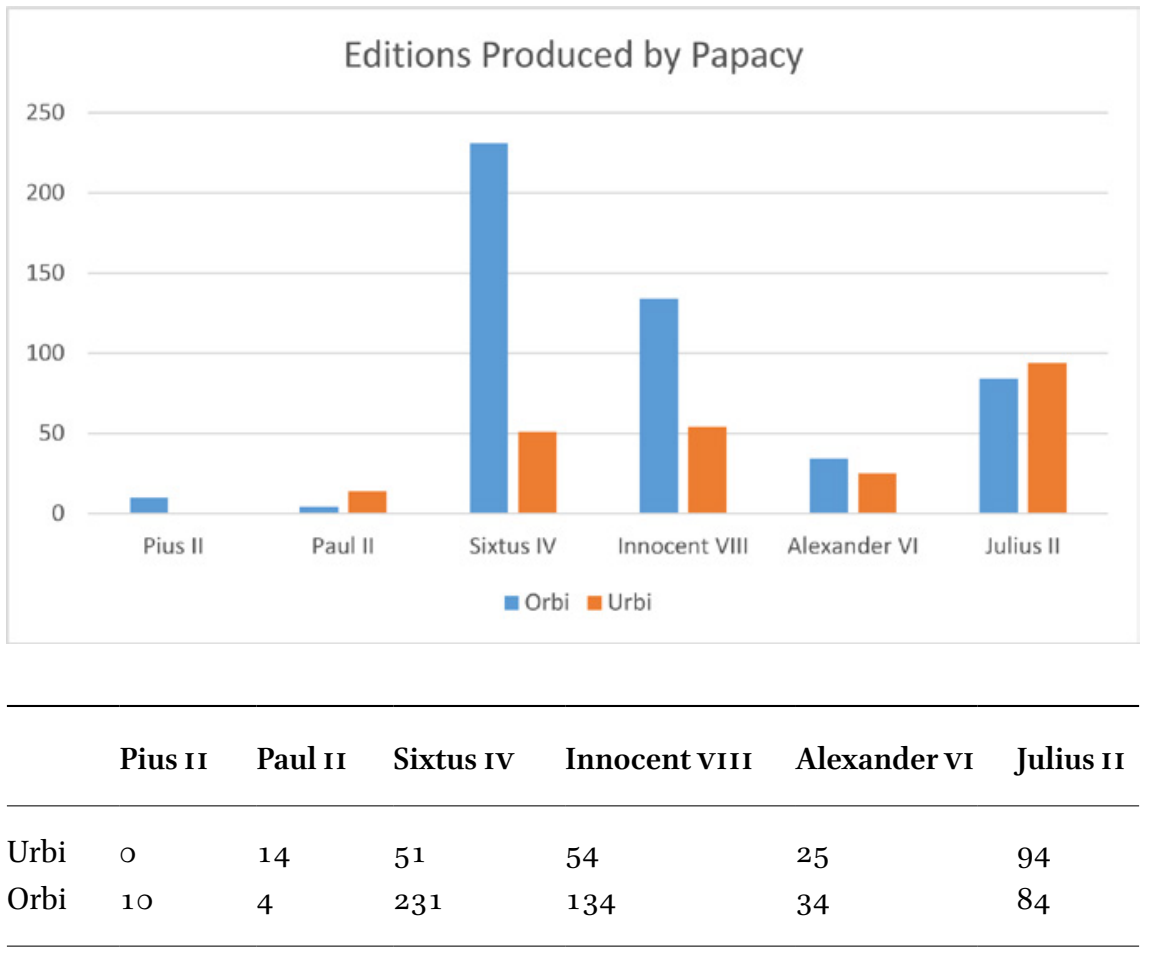

Moreover, during Julius' papacy, for the first time we see a substantial number of papal decrees printed in support of political initiatives: for example, Julius' campaigns to recover territory in northern Italy lost to rival powers during the French invasions of the 149os; his attempts to assert the supremacy of his office over challenges from insubordinate cardinals and secular princes; and his effort to reform the church at the ecumenical council he convened at

the British Library, and the preliminary censuses of sixteenth-century editions attributed to or signed by Giacomo Mazzocchi, Eucharius and Marcello Silber, and Etienne Guillery: Fernanda Ascarelli, Annali tipografici di Giacomo Mazzocchi (Florence: Sansoni, 1961); Francesco Barberi, 'Stefano Guillery e le sue edizioni romane', in Berta Maracchi Biagiarelli and Dennis E. Rhodes (eds.), Studi offerti a Roberto Ridolfi (Florence: Olschki, 1973), pp. 95-145; Alberto Tinto, Gli annali tipografici di Eucario e Marcello Silber (15011527) (Florence: Olschki, 1968). On the difficulty of making attributions to these printers, who routinely shared types and woodcuts, see Martin Davies, 'Besicken and Guillery', in Denis V. Reidy (ed.), The Italian Book 1465-1800, Studies presented to Dennis E. Rhodes on his 7oth birthday (London: British Library, 1993), pp. 35-54. My tally of domestic (urbi) production for Julius includes editions printed within the papal states (i.e. not only in Rome but also in Bologna and Forli). 
the Lateran in 1512. Such 'political' publications actually outnumber the publications of chancery rules, bureaucratic instructions, and more everyday legislative publications. And while foreign printers continued to publish papal documents of local interest under Julius (mostly indulgences and privileges for local churches), we also see, for the first time, regular republication abroad of the 'political' bulls that were first printed in Rome.

Thus, the figure of 84 foreign publications attributed to Julius is somewhat deceptive. This figure includes $5^{1}$ bulls concerning indulgences or special privileges for local churches, the same sort of texts as were printed in great numbers under Sixtus IV and Innocent VIII. ${ }^{17}$ But the remaining 33 publications treat political matters, including bulls of warning and excommunication against political rivals and bulls promoting Julius' council in Rome and condemning a rival assembly backed by King Louis XII of France. Most of these bulls were printed in their original Latin, but some also appeared in vernacular translations: in German, French, and Italian. Taken together with 59 editions of political bulls printed in Rome and another forty or so administrative bulls also printed in Rome during his reign, we arrive at a total of 127 editions of bulls printed in Julius' name and with the active or at least tacit support of the papal chancery. Subtracting the books of administrative regulations and instructions, we are still left with around 75 different editions of papal bulls concerning political affairs, by far the largest number of any Renaissance pope. Thus it was under Julius, some fifty years after the invention of printing with movable type and forty years after its arrival in Italy, that the papacy finally came regularly to use print as a medium for political discourse, diplomacy, popular persuasion, and the conduct of war.

\section{Papal Politics in Print}

Here, it may be useful to consider what I mean by "political" print. There had been some instances of political publication by the fifteenth-century popes. Sixtus IV used the press to publish not only administrative documents but also a few pieces of diplomatic and political propaganda. In 1478, he backed the infamous Pazzi conspiracy against the Medici regime in Florence. The plot

17 The vast majority of these were printed in Spain. USTC records 33 Spanish indulgences; nine similar documents printed in France or Francophone Switzerland (in Paris, Bourges, Geneva, Chambery, Annecy); five printed in German or German-speaking Swiss cities (Leipzig, Constance, Zurich); two in the Low Countries (Antwerp, 's-Hertogenbosch); and two in London. 
fell apart after the ringleaders assassinated Giuliano de' Medici but failed to murder his brother Lorenzo, and the Florentines captured and killed several conspirators including Francesco Salviati, the archbishop of Pisa. A furious Sixtus IV then excommunicated Lorenzo, ostensibly for violating the ecclesiastical immunities of the archbishop of Pisa but in fact - and as Lorenzo himself memorably put it - for the crime of not allowing himself to be murdered. ${ }^{18}$ On 4 June 1478, Sixtus had a bull of excommunication posted on the doors of St. Peter's in Rome (the traditional way of publishing ecclesiastical penalties of this sort) and within five days, copies of the text had been printed in the city.19 In a letter of 9 June, the Milanese ambassadors in Rome described the bull as 'published and even printed' (hora che le sonno publicate et a stampa) and on 12 June, the Milanese ambassador in Venice reported that a copy of the printed bull (processo delle ... censure impresso a stampa a Roma) had arrived there as well. ${ }^{20}$

Ineffabilis was the first salvo in a war of words that lasted all summer, with printed charges and counter-charges flying back and forth between Florence and Rome. Sixtus' bull had been entrusted to two different printing houses for publication; one produced it as a quarto pamphlet, some ten pages long, while a second press issued an edition in folio, its dense text filling three large pages of a single folded sheet. ${ }^{21}$ Neither edition does much to announce its author or contents, although the folio edition does print the words Sixtus iii Pont. Max. as a sort of subscription at the end of the text. Even so, as the length of the

18 Lauro Martines, April Blood: Florence and the Plot against the Medici (Oxford: Oxford University Press, 2003), pp. 178-185; Marcello Simonetta, The Montefeltro Conspiracy: A Renaissance Mystery Uncoded (New York: Doubleday, 2008); Marcello Simonetta (ed.), La congiura della verità (Naples: La Scuola di Pitagora, 2012); Tobias Daniels, 'Die Pazzi-Verschwörung, der Buchdruck und die Rezeption in Deutschland. Zur politischen Propaganda in der Renaissance', Gutenberg-Jahrbuch, 87 (2012), pp. 109-120 and Tobias Daniels, La congiura dei Pazzi: i documenti del conflitto fra Lorenzo de' Medici e Sisto IV (Florence: Edifir, 2013).

19 Bull 1 June 1478 "Ineffabilis et summi patris providentia," edited by Daniels, La congiura, pp. 105-12, with analysis at pp. 23-28; Martines, April Blood, p. 177. The Milanese ambassadors in Rome wrote on 5 June that the promulgation had occurred the previous day: Nicolai Rubinstein (ed.), Lorenzo de' Medici, Lettere, vol. 3 (Florence: Giunti, 1977), p. 46. For 10 June, see Daniels, La congiura, p. 23, p. 27.

$20 \quad$ Quoted by Rubinstein in Lorenzo de' Medici, Lettere, 3.48. The bull was published in Naples on 14 June: Rubinstein, Lettere, 3.75, n. 2.

21 Bulla 1 June 1478 Ineffabilis et summi patris providentia [Rome: Johannes Bulle, after 1 June 1478] (isoo54500o); Bulla 1 June 1478 Ineffabilis et summi patris providentia [Rome:] Johannes de Monteferrato and Rolandus de Burgundia, [after 1 June 1478] (isoo54550o); Albano Sorbelli, 'La scomunica di Lorenzo de' Medici in un raro incunabolo romano', L'Archiginnasio, 31 (1937), pp. 331-335. 
bull, its sensational rhetoric, and its patterns of distribution all suggest, the text was intended for a broader audience than just those Florentines whom it condemned. Sixtus himself wrote to Federico da Montefeltro in July 1478, explaining his publicity campaign: 'We have sent many ambassadors to the king of France with our arguments, and likewise we have sent others to other princes, such as the emperor, the king of Hungary, the king of Spain, and all the rest. Moreover our bull, which has been put into print before the whole world, will demonstrate the rightness of our cause. ${ }^{22}$ All told, nearly a dozen editions of Sistine bulls and briefs against Florence were published in Rome over the next two years, and more would follow from Sixtus in the course of the War of Ferrara, which he fought against Venice between 1482-4, and in his campaign to suppress a revival of the conciliar movement in upper Germany during these same years. ${ }^{23}$

But this early spate of political publications was short-lived. Innocent vIII and Alexander vi were less inclined to use the press to pursue political goals; in fact, examples of publications by these popes that might count as "political" are quite hard to come by. Innocent's condemnation of Pico della Mirandola's 900 theses was printed once in Rome. ${ }^{24}$ His brief condemning the capture of Maximilian I by Flemish troops in 1488 was printed once in Germany (with the alarming title Maledictio adversus Flamingos). ${ }^{25}$ Alexander vi was the subject of an ingenious press campaign organised by the reforming friar Girolamo Savonarola and his followers in Florence, who published dozens of vernacular tracts calling for reform in the church and castigating Pope Alexander for Italy's woes. ${ }^{26}$ It is an extraordinary and hard-to-explain fact that only one example of a papal riposte to Savonarola survives in print: an Italian translation of Alexander's brief of 12 May 1497 concerning Savonarola's excommunication,

22 Sixtus IV to Federico da Montefeltro, 5 July 1478, in Alison Brown (ed.), Bartolomeo Scala, Humanistic and Political Writings (Tempe: Medieval and renaissance texts and studies, 1997), p. 159, n. 68: "Al re di Francia habbiamo mandato multi nuncii con nostre justificationi, similiter alli altri Principi, come lo è l'Imperatore, Re di Ungheria, di Spagna, e tutti li altri. Praeterea la Bolla nostra, quale è stata posta in stampa a tutto il mondo, dimostrerà nostra justificatione" (italics mine).

23 I discuss these early pamphlet wars in Chapters 3 and 4 of my forthcoming book Papal Bull.

24 Bulla "Etsi ex iniuncto" condemnatoria libelli Conclusionum DCCCC Joannis Pici Mirandulani (iioo1089oo).

25 Mandatum apostolicum et maledictio adversus Brugenses et Flamingos (iioo136750).

26 Donald Weinstein and Valerie R. Hotchkiss (eds.), Girolamo Savonarola: Piety, Prophecy, and Politics in Renaissance Florence (Dallas: Bridwell Library, 1994), pp. 65-71. 
and this was printed in Florence, not in Rome. ${ }^{27}$ In short, while Sixtus IV early on grasped the political possibilities of print, he was the only fifteenth-century pope to do so. The next phase of papal printing would only open with the reign of Julius II.

\section{Print and Politics in the Reign of Julius II}

Giuliano della Rovere was Sixtus IV's nephew and had been one of the old pope's closest political advisors. When he was elected Pope Julius II in the summer of 1503 , he resumed his uncle's aggressive foreign policies as well as his liberal use of ecclesiastical penalties as a diplomatic tool. ${ }^{28}$ Julius and his chancery also revived - and then dramatically expanded on - Sixtus' practice of issuing bulls against political opponents and rivals and broadcasting them through the medium of the press. Over the ten years of Julius' pontificate, dozens of bulls, briefs, and other ecclesiastical documents would appear in print at a steadily increasing rate. Alongside a constant stream of legal and administrative publications, there was, for example, Julius' bull against the Bentivoglio family of Bologna, issued during his campaign to reassert control over that and other cities in the northern papal states and printed twice in Rome in 1506. ${ }^{29}$ There was a formidable monitorium against the people and clergy of Venice, printed at least fourteen times in the months after Julius joined the Italian league arrayed against Venice in the spring of $1509 .{ }^{30}$ And four different printed bulls of warning, excommunication, and interdict were issued against Alfonso d'Este, duke of Ferrara, and the French armies then occupying Milan, printed in a total of sixteen different editions. ${ }^{31}$

In 1511, when a group of cardinals sympathetic to France withdrew from Rome and attempted to call Julius to account before a new council of the church at Pisa, the Julian chancery issued yet more bulls of excommunication and privation (stripping the cardinals of their ecclesiastical offices): a half dozen texts printed and reprinted in some 17 distinct editions. ${ }^{32}$ Julius'

27 iaoo36980o. The text of this brief appeared in print again in several later editions alongside the text of the processo against Savonarola; this composite edition was printed twice in Florence, twice in Venice, and once in Rome.

28 Christine Shaw, Julius II: The Warrior Pope (Oxford: Blackwell, 1993). An excellent study of Julius' portrayal in European popular print is Massimo Rospocher, Il papa guerriero: Giulio II nello spazio pubblico europeo (Bologna: Il Mulino, 2015).

29 See entry 1.1. in the appendix.

30 See entry 1.3. in the appendix.

31 Entries 1.4-1.7 in the appendix.

32 Entries 2.2-2.7 in the appendix. 
ultimate response to the Pisan conciliabulum was to convene a council of his own, Lateran v, which opened in Rome in 1512 and whose deliberations and decrees were published in even greater numbers. Including the bull announcing the council in July 1511, eight bulls were published before Julius' death in February, 1513, in 27 different editions. ${ }^{33}$ The scale of Julian publication was thus far larger than Sixtus' or any other previous pope's. The total count of Julian bulls regarding political or ecclesiastical controversies surpasses 80 different editions of 23 different texts, printed not only within the papal states in Rome and Bologna but also in cities much further afield, including Venice, Ferrara, Nuremberg, Augsburg, Leipzig, Burgos, Paris, and Lyon.

In the satirical dialogue Julius Exclusus, long attributed to Erasmus, St. Peter describes Julius as a Jupiter on Olympus hurling the 'thunderbolts' of his bulls at anyone who displeased him. ${ }^{34}$ These tallies of Julian printed bulls certainly support the image of a pope who did not hesitate to draw the spiritual sword against his enemies. But the bulls Julius hurled did not just fly directly to their targets, in the form of a manuscript document delivered in person. Printed for the whole of Europe to read, they performed a dual function, delivering both private, legal sentences and very public and embarrassing rebukes.

Even as he put far more of his decrees into print than any previous pope, Julius had no official printer; it was only in the middle decades of the sixteenth century that the position of papal printer was properly established. ${ }^{35}$ In the first two decades of the sixteenth century, the papal chancery entrusted its documents to several different, independent printers in Rome, including Johannes Besicken, Eucharius and Marcello Silber, Giacomo Mazzocchi, Etienne Guillery, and Johannes Beplin. ${ }^{36}$ These printers had their shops in Campo Marzio, in the narrow, busy streets around the markets at Campo de' Fiori and Piazza Navona,

33 Appendix, 3.1-3.7. For a discussion of their contents, see Nelson H. Minnich, 'The Images of Julius II in the Acta of the councils of Pisa-Milan-Asti-Lyons (1511-12) and Lateran V (1512-1517)', in his Councils of the Catholic Reformation (Aldershot: Ashgate, 2008), study X.

Erasmus, The Praise of Folly and Other Writings, transl. Robert M. Adams (New York: Norton, 1989), pp. 145, 149-50.

35 The Roman printer Francesco Calvo called himself impressore apostolico in an edition of 1528; Antonio Blado, long established as a printer in Rome, signed himself tipografo camerale in 1535, a year after Calvo quit the city: Francesco Barberi, "Blado, Antonio," in Dizionario biografico degli italiani 10 (Rome: Istituto dell'Enciclopedia italiana, 1968), pp. 753-57. See also Paolo Sachet, 'Il Contratto tra Paolo Manuzio e la Camera Apostolica (2 Maggio 1561): La Creazione della prima Stamperia Vaticana Privilegiata', La Bibliofilía 115 (2013), pp. 245-62 and Publishing for the Popes: the Roman Curia and the Use of Printing, 1527-1555 (Leiden: Brill, 2020).

36 Massimo Miglio, Saggi di stampa: Tipografi e cultura a Roma nel Quattrocento (Rome: Roma nel Rinascimento, 2002); Concetta Bianca, 'Le strade della 'sancta ars:' La stampa e la curia a Roma nel XV secolo', in Cristina Dondi etc. (eds.), La stampa romana nella città dei papi e in Europa, (Vatican City: Biblioteca Apostolica Vaticana, 2016), pp. 1-9. 
many of them quite near the papal chancery in its old premises on the via dei Banchi, in what is now Palazzo Sforza-Cesarini. All of them did job work for the chancery at various times. Although Mazzocchi claimed a papal mandate or privilege in some of his editions, it does not seem to have had much of an effect: almost every papal document that was printed was printed in multiple editions, often simultaneously by several different Roman printers. ${ }^{37}$

Under the della Rovere pope, there was not just an increase in the production of papal documents and a change in the kind of texts that appeared; there were also dramatic developments in the form and format in which they were printed. The printed bulls of previous popes were visually undistinguished. Either large bifolia or slightly longer, quarto pamphlets, they were usually printed in a single fount of type (usually gothic, and usually quite small), with little in the way of titles or other paratexts to announce their contents, and no visual or graphical elements at all.

Julian bulls, by contrast, were innovative in both form and content. Though produced by different printers, they were all small, pamphlet-size productions that feature distinct titles explaining their contents, and most of them included Julius' name in type and his papal stemma in woodcut on the first page, as well as the titles set in either large type or shaped type (or both); in most cases, the first page of the pamphlet functioned as a true title page. ${ }^{38}$

These design innovations make it worth recalling a few things about the documentary form of a papal bull. Technically, a bull is no more than a letter from the pope conveying some official decree, sentence, judgement, or law. Bulls could convey dire pronouncements, like a decree of excommunication, but they could also be far less combative documents, issued to elevate a bishop, canonise a saint, establish a university, or grant certain privileges or rights. What made a bull a bull was not its content, but its form. A typical medieval bull would have been written out on a single parchment sheet; the opening words would follow a set pattern, and the text would conclude with particular verbal formulae relating to the time, place, and circumstances of its signing. Graphic signs could be used to certify the authenticity of the document, such as exaggeratedly tall letters used in the opening sentence; a rotula,

37 E.g. Monitorium contra Venetos (Rome: Giacomo Mazzocchi, [1509]), fol. 12v: "Impressum ... de mandato prelibati Sanct. D.N. domini Iulii divina providentia pape II."

38 Entry 1.1.a (appendix) has a simple title in the same type as the body of the text; some Roman editions of entries 1.2-1.3 (1508-9) feature a title in larger type and a small woodcut stemma inset into the start of the text; with entry 1.4., a bull against Alfonso d'Este published in August 1510, we see the for the first time full title pages featuring descriptive titles in large type, large woodcut stemme, and, occasionally, woodcut borders or frames. Most subsequent editions follow this pattern. 


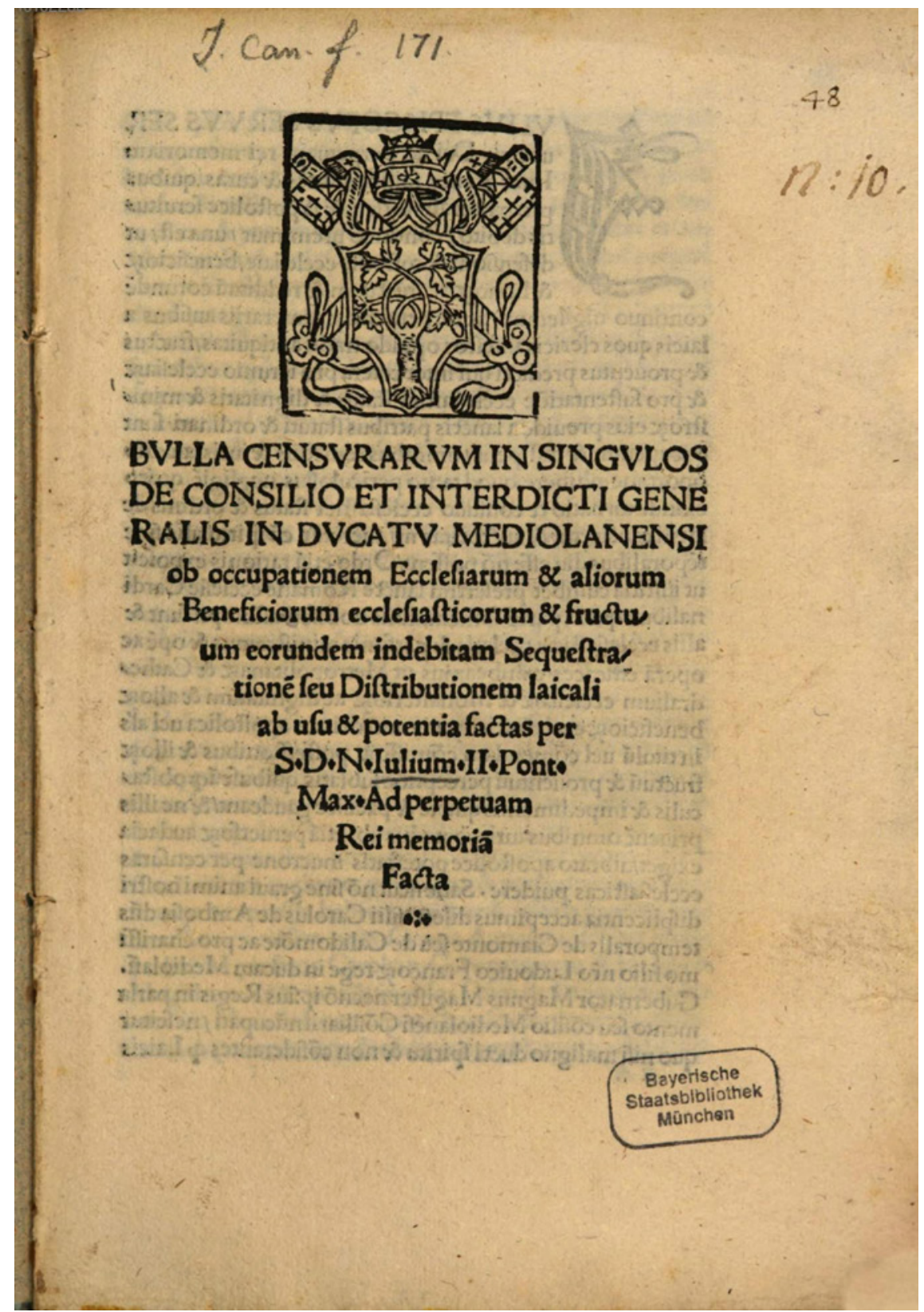

FIGURE 12.1 Julius II, Bulla censurarum [Rome, ca. 1510] MUNICH, BSB, 4 F. 4 J.CAN.F. 171, FOL. 1R 


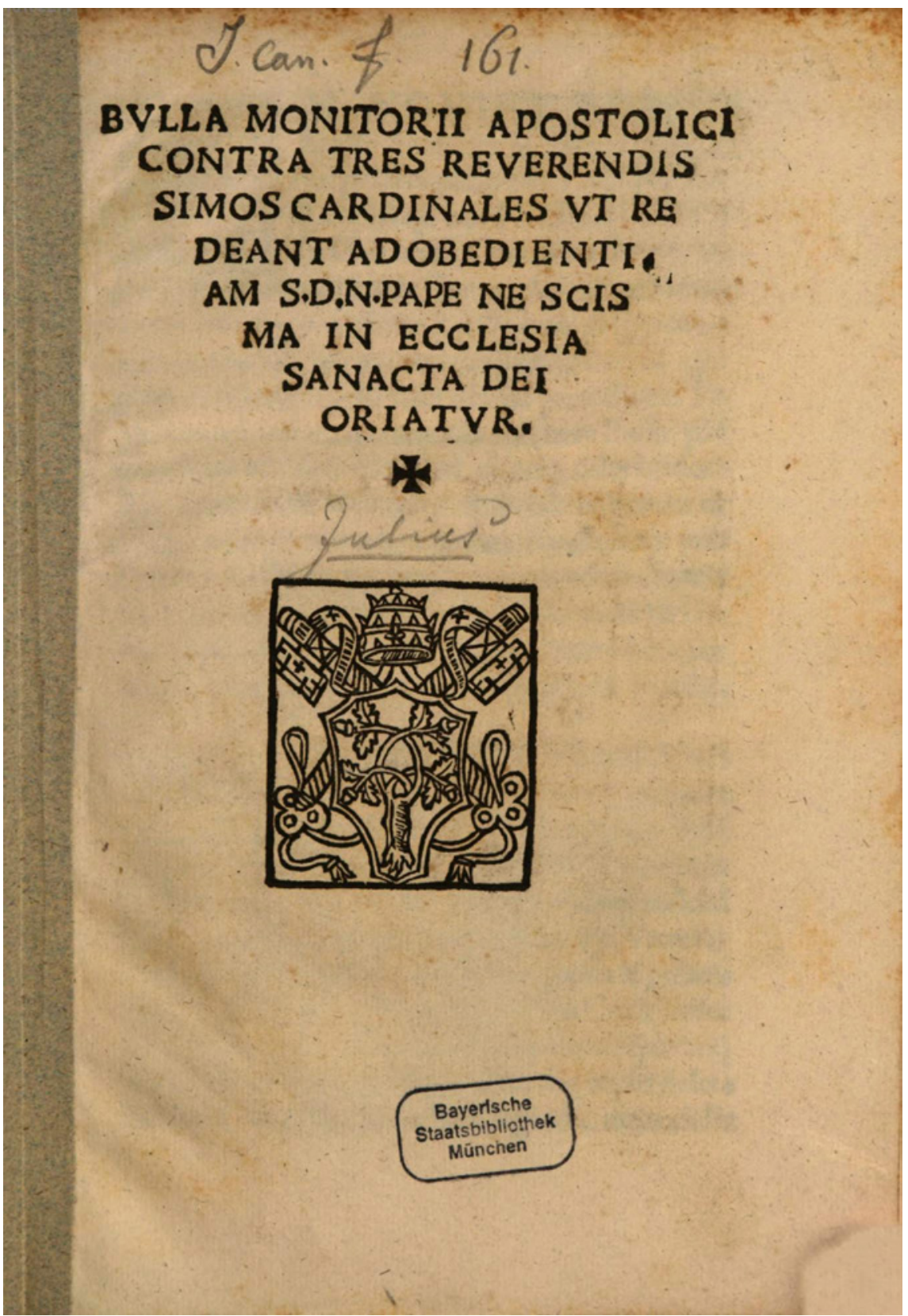

FIGURE 12.2 Julius II, Bulla monitorii apostolici contra tres reverendissimos cardinales

[Rome: Giacomo Mazzocchi or Etienne Guillery, 1511] MUNICH, BSB, 4 J.CAN.F 161, FOL. 1 R 
or handdrawn circle containing the monogram of the current pope; and manuscript signatures applied by the pope, his secretaries, or cardinals. The parchment as a whole was sewn with special cords, usually of red and yellow silk, twisted together and then pressed inside a lead seal, or bulla, stamped with images of Peter and Paul and the name of the current pope. It was the bulla that made a document a bull.

There was much in the medieval bull that would have been difficult if not impossible to reproduce in print - the seal, the cords, special lettering, and so on. But the evolution in format from parchment sheet to printed pamphlet was not pre-ordained, nor did it have to be as dramatic as it was. The development of the Julian pamphlet, with its title page, woodcut stemma, varying sizes of type, and narrower text block, was a conscious choice, one made for the sake of portability, legibility, and visual impact.

Moreover, Roman printers regularly employed woodcut artisans, and could easily have commissioned cuts representing a Julian rota or a Peter-and-Paul seal. Mazzocchi, in fact, did develop a hybrid rota with a woodcut circle and monograms set in type, but it appears only once or twice in his entire oeuvre. ${ }^{39}$

Later in the century, Roman printers would introduce woodcut figures of Peter and Paul, placed on either side of the text in broadside bulls and decrees. During Julius' reign, however, printers chose (or perhaps, were instructed) to use Julius' personal stemma, not the figures of the apostles, as the authenticating image for each bull, and to give the papal arms far greater prominence on the cover of the pamphlet than earlier authenticating signs had held on the original document. The arms visually branded the front cover of the pamphlet (the page that would have been on most visible as the book was displayed in booksellers' stalls or as it passed from reader to reader) with the most recognisable emblem of the reigning pope. These images travelled, too: the Nuremberg printer Johann Weissenburger had a cut of the Julian stemma modelled so closely on that used by the Roman printer Marcello Silber that his editions have sometimes been mistaken for Silber's. ${ }^{40}$ Weissenburger then had a second cut of the Julian stemma made, which he used in other editions of Julian bulls. ${ }^{41}$ The Venetian printer Franciscus Lucensis printed a small della Rovere oak tree, on a plain shield, on the title pages of his Julian bulls, alongside the winged lion of St. Mark and some decorative mermaids - a politic move for a printer publishing in the independent republic. ${ }^{42}$

39 E.g. Appendix 2.1.a, 2.1.b.

$40 \quad$ Appendix 2.1.j, 2.2.d, 2.5.d, 2.7.d.

41 Appendix 2.1.j(var), 2.2.e.

42 See entry 1.4.d, 1.6.d. 


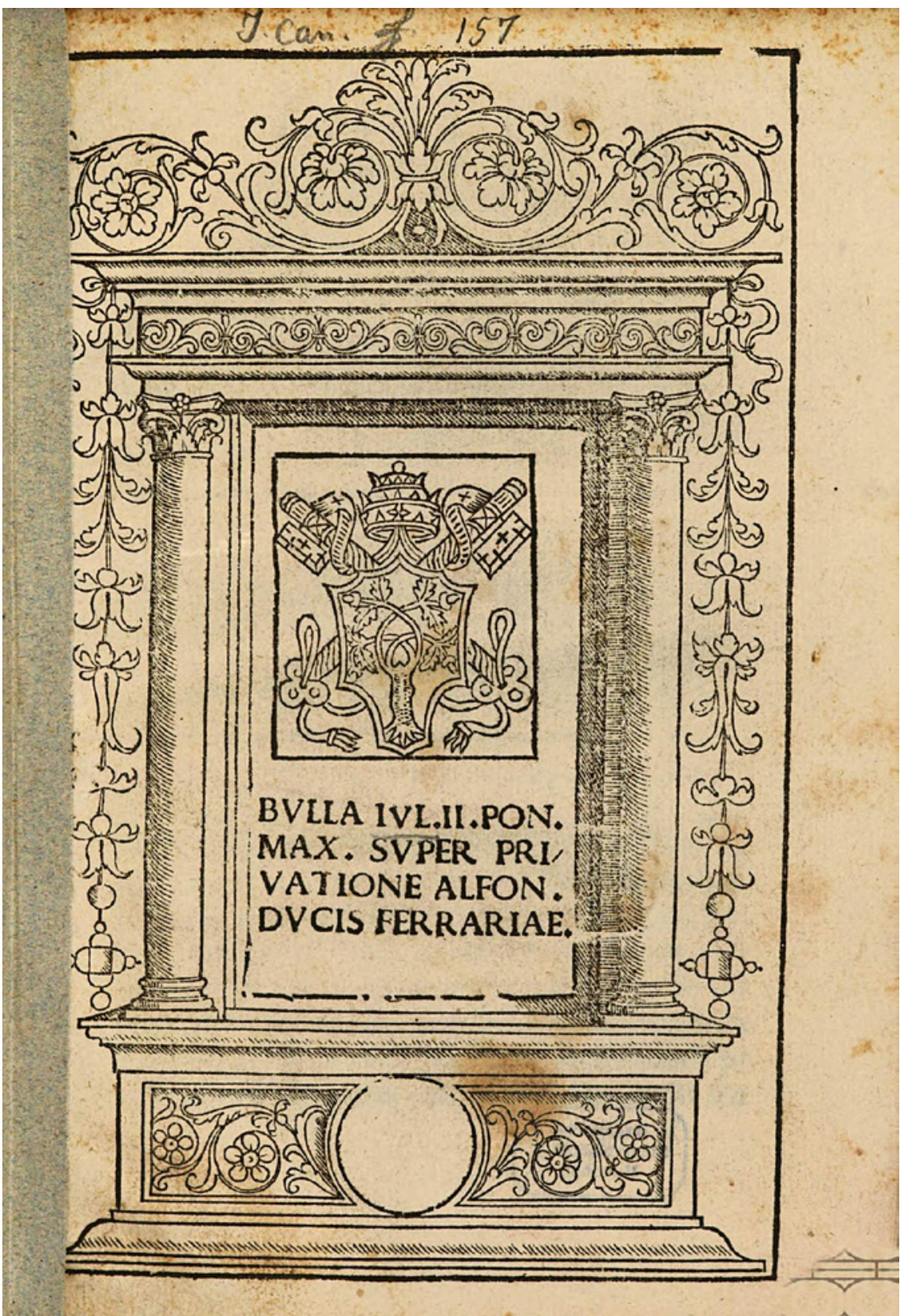

FIGURE 12.3 Julius II, Bulla super sententia privationis [Rome: Marcello Silber, 1511] MUNICH, BSB, RES/4 J.CAN.F. 26\#BEIBD.28, FOL. 1R 


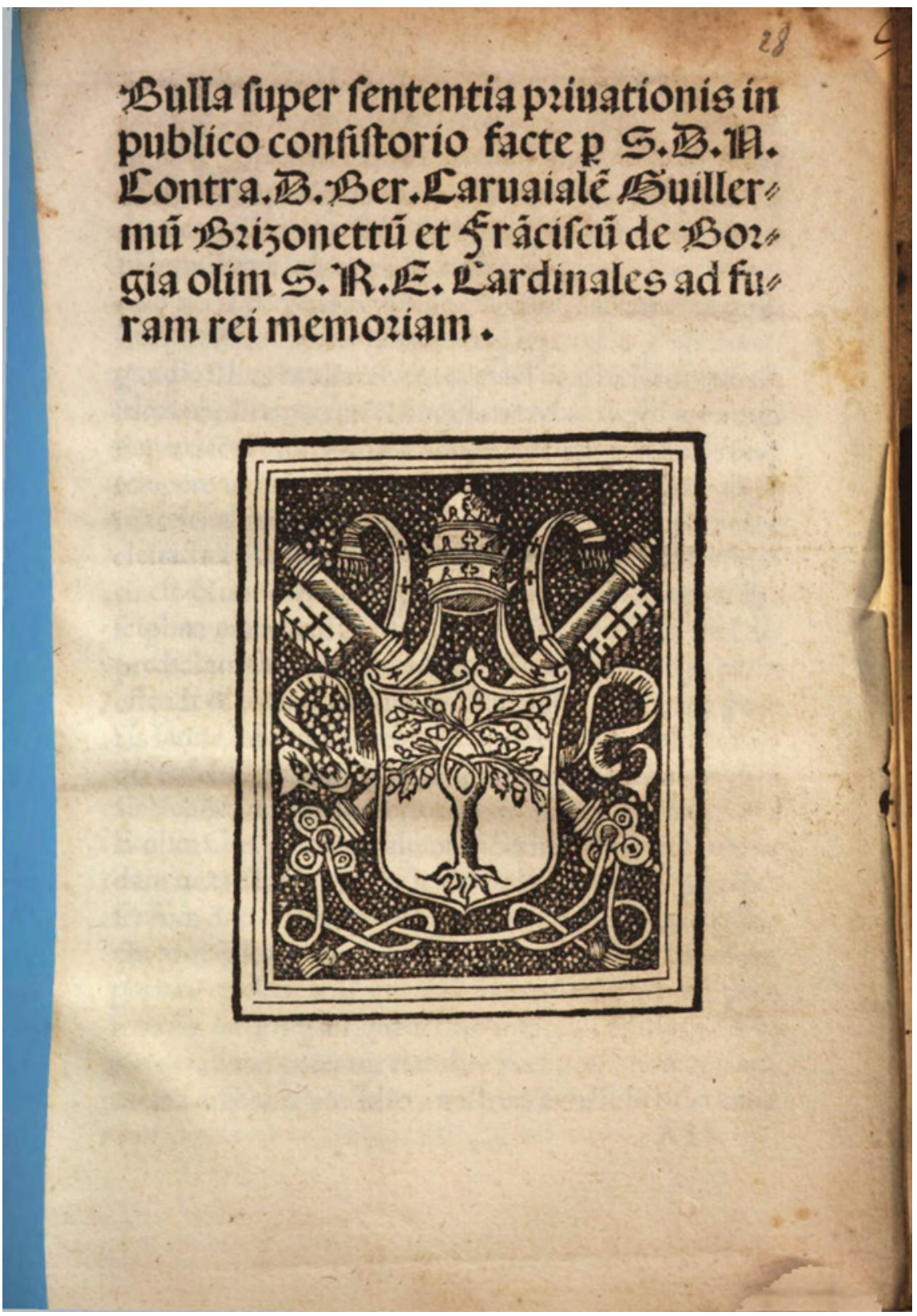

FIGURE 12.4 Julius II, Bulla super sententia privationis ([Rome: Etienne Guillery?, 1511]) MUNICH, BSB, RES/4 J.CAN.F. 26\#BEIBD.28, FOL. 1R 

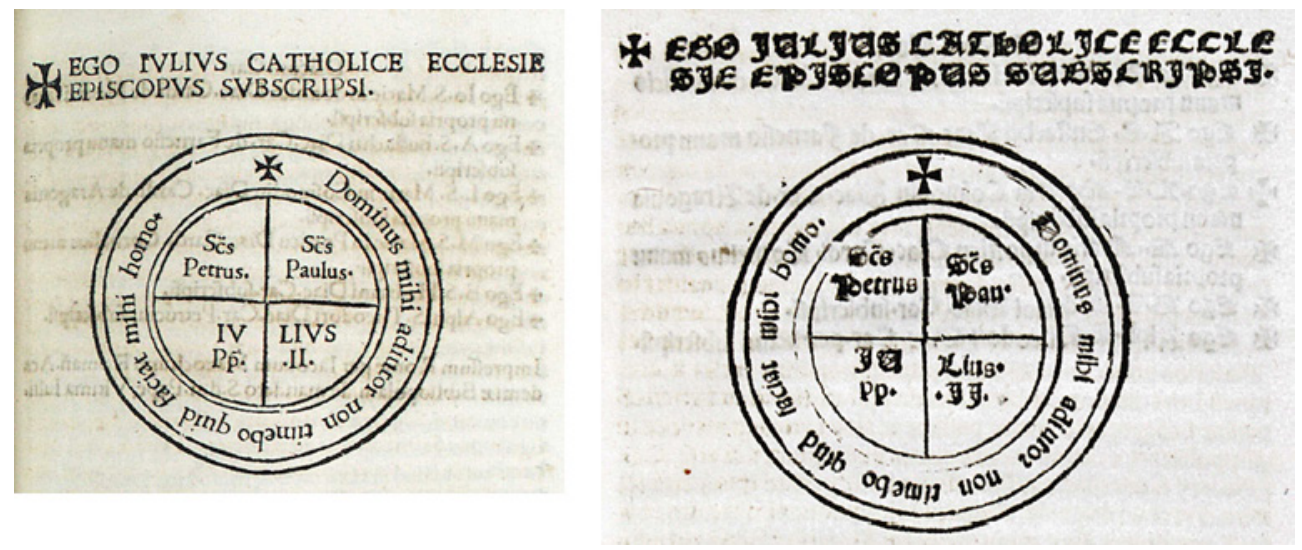

FIGURE 12.5 Printed rotule in editions of Julius II, Bulla intimationis [Rome, 1511]

The quarto format also allowed the text of the bull to run to several pages, leaving room for more rhetorical amplification than a single sheet of parchment might. Some pamphlet bulls run to two or more quires. Thus the composers of the bull could expand dramatically upon their theme; from a compact legal proclamation, the bull grew to an extensive rhetorical production, in which the pope, speaking directly to the faithful, could elaborate on the political situation he was confronting and address discursive appeals to the emotions and sensibilities of a wider reading public. Julius' Monitorium against the Venetians, published in multiple editions in the spring of 1509 in the run-up to League of Cambrai's war against Venice, runs to sixteen pages in the gothic-type edition of Eucharius Silber, and 24 pages in Mazzocchi's edition printed in a larger roman font. ${ }^{43}$ One German translation of the document is 32 pages long. ${ }^{44}$ Mazzocchi's edition of the 1510 bull stripping Alfonso d'Este of his dukedom is also 32 pages long. The pope's 1511 bull convening the Fifth Lateran Council, published in eleven different Latin editions, fills anywhere from twelve to twenty pages; an Italian translation is sixteen pages long, while two editions of a German translation, published in Leipzig, run to twenty pages each. ${ }^{45}$

Alongside these steadily lengthening bulls, the Julian chancery also had new types of documents printed to support the pope in his various conflicts documents of the sort that previous popes may well have issued in their own diplomatic conflicts, but not in print. For example, Julius issued numerous bulls of warning as well as sentence. His 1509 Monitorium against Venice

\footnotetext{
43 Appendix 1.3.a-f.

44 Appendix 1.3.i.

45 Appendix 2.1.a-n.
} 


\section{c) bullaultimaCon uocationis et intuitationis Ear" oinaliii abrentiū et •selatozun gallicenationis ad celebrationê Eoncilii Zateraneî. cuí oeclara: tionenullitatis geftozí per Eon

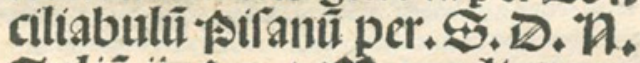 żuliui.tí. Pont.2Aar.edita.}

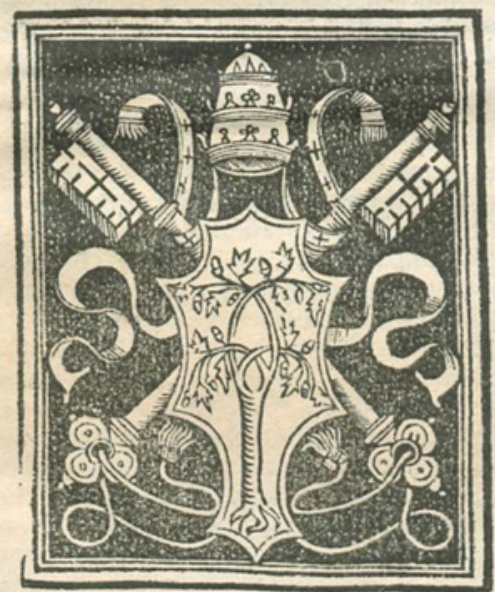

FIGURE 12.6 Julius II, Bulla ultima convocationis et invitationis [Nuremberg: Johann Weissenburger, 1512] MUNICH, BSB, 4 CONC. 102, FOL. 1R 
conveyed dire threats against the Venetians: they had thirty days to relinquish their claims to certain cities in the Romagna or else Julius would level the interdict on the city and make preparations for open war. ${ }^{46}$ Similar bulls of warning were published in 1511, directing a group of schismatic cardinals to abandon the Pisan council and restore their obedience to Julius or be stripped of their titles and offices; and in 1512, warning the bishops in France to keep their distance from the French king's schismatic assembly or face loss of office and excommunication. ${ }^{47}$ The propagandistic value of printing such threats was clear: giving his opponents fair warning that their behaviour could incur dire spiritual and temporal penalties, and then publicizing that threat as widely as possible, the pope hoped to leverage public opinion to force his opponents whether Venetians or cardinals or clergy - to back down before proceeding to much more severe decrees of interdict or demotion. Alternately, the bulls may have been intended to offer a set of conditions which their targets would very likely reject - thus providing Julius with legitimate casus belli against the Venetians, and a legitimate reason to excommunicate the schismatic cardinals and clergy. In all three cases, the pope's warnings were not heeded and in the latter two cases, further bulls pronouncing more serious penalties soon followed them into print.

As policy measures, then, monitoria were not successful, but as pieces of public relations, they rather were: they broadcast to as broad an audience as possible the fact of the pope's righteous anger, the depravity of his opponents' behavior, and the severity of the penalties they faced. Print thus provided support for a complex ecclesiastical strategy involving exploding offers and the pressure of public opinion. After demoting and excommunicating the rebel cardinals, Julius composed a brief explaining his actions to the Christian princes and this, too, was published in numerous editions, both in Rome and north of the Alps, to justify the papal sentence and appeal to the faithful for support. ${ }^{48}$ These were tactics that future popes would deploy with increasing frequency against political as well as doctrinal opponents, including Luther.

Another innovation was the recycling or reissue of older bulls and documents. In the controversy over the rival councils of Pisa and Lateran v, Julius was fighting a number of parallel battles. Louis XII was seeking to solidify his diplomatic and political presence in Italy, where the French controlled Milan and threatened to overtake the entire peninsula, but Louis was also trying to

\footnotetext{
46 Appendix 1.3.

$47 \quad$ Appendix 2.2; Appendix 2.6.

48 Appendix 2.5.a-d: three editions printed in Rome by Mazzocchi and Guillery and one in Nuremberg by Weissenburger.
} 
secure more control over the church in France - over revenues and appointments, for example, and rights that might allow the establishment of something like a Gallican church. In promoting a new council at Pisa, Louis and the cardinals who adhered to him sought to place serious restrictions on the pope's authority over ecclesiastical affairs in France as well as his claims to arbiter political affairs in Italy. ${ }^{49}$ In response, Julius issued multiple bulls against the adherents of the Pisan council and to further push back against its claims, the Julian chancery also dug into the archives, reissuing and then printing earlier documents issued against earlier challengers: for example, Pius II's 1460 bull Execrabilis, outlawing appeals to a general council by anyone other than the pope; Louis XI's 1462 renunciation of the Pragmatic Sanction of Bourges (an earlier attempt by a French king to carve out Gallican privileges for the church in France); a decree of the Council of Constance, in which the right to call a future council was vested exclusively in the pope; and even the Donation of Constantine, the supposed foundation of all papal claims to temporal power over the Roman Empire in the west. ${ }^{50}$ These reissues of earlier ecclesiastical legislation (real or confected) appeared in the same types and formats as the new bulls.

Finally, the Julian chancery extended its branding in print to the more prosaic category of administrative bulls, the same documents as had been issued in print by every pope since Paul II, to establish or reinforce the policies and principles under which their administration would operate. Julius published bulls condemning simony in future papal elections, regulating the payment of fees by episcopal appointees, and setting out the privileges and immunities allowed to different ranks of curial officials. He published regulations for the colleges of scriptors and abbreviators, a code of practice for the chancery in general, a reform of curial offices, an attempt to reorganize the prosecution of legal cases within Rome, regulations for the drawing up of wills and bequests of property, and bulls condemning bandits, thieves, and anyone violating the immunities of ecclesiastical personnel. Such publications had been

49 Nelson H. Minnich, 'Rite convocare ac congregare procedereque: the Struggle between the Councils of Pisa-Milan-Asti-Lyons and Lateran V', in his Councils of the Catholic Reformation (Aldershot: Ashgate, 2008), study IX.

50 For the 1460 bull consult entry 1.8 in the appendix; for the letter of Louis XI see Littere clare memorie Ludovici XI Francorum regis Christianissimi super abrogatione pragmatice sanctionis in quarta sessione sacroscancti Lateranensis concilii publice lecte et recitate [Rome: Marcello Silber, 1512], ustc 838702. For the decree of the Council of Constance, consult Appendix 2.1.a and reprints, fol. 8v: "Constitutio Concilii Constantiensis de auctoritate et potestate sacrorum generalium conciliorum temporibusque et modis eadem convocandi et celebrandi" and for the Donatio Constantini, published in Rome in three different editions between 1504 and 1513, see usTC 826855; 955616; 801952. 


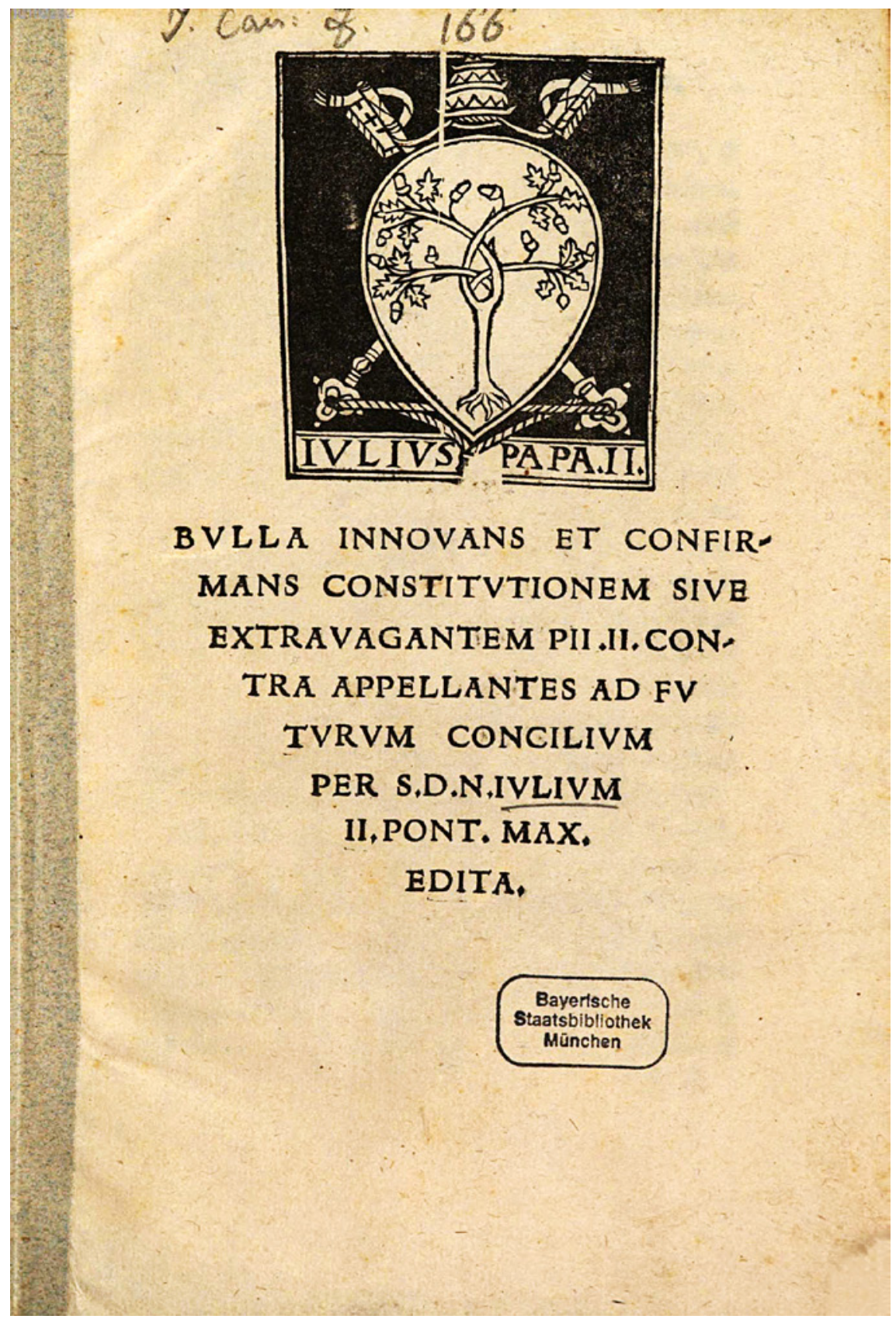

FIGURE 12.7 Julius II, Bulla innovans et confirmans constitutionem ... Pii II contra appellantes ad futurum concilium [Rome, 1510]

MUNICH, BSB, 4 J.CAN.F. 166, FOL. 1R 

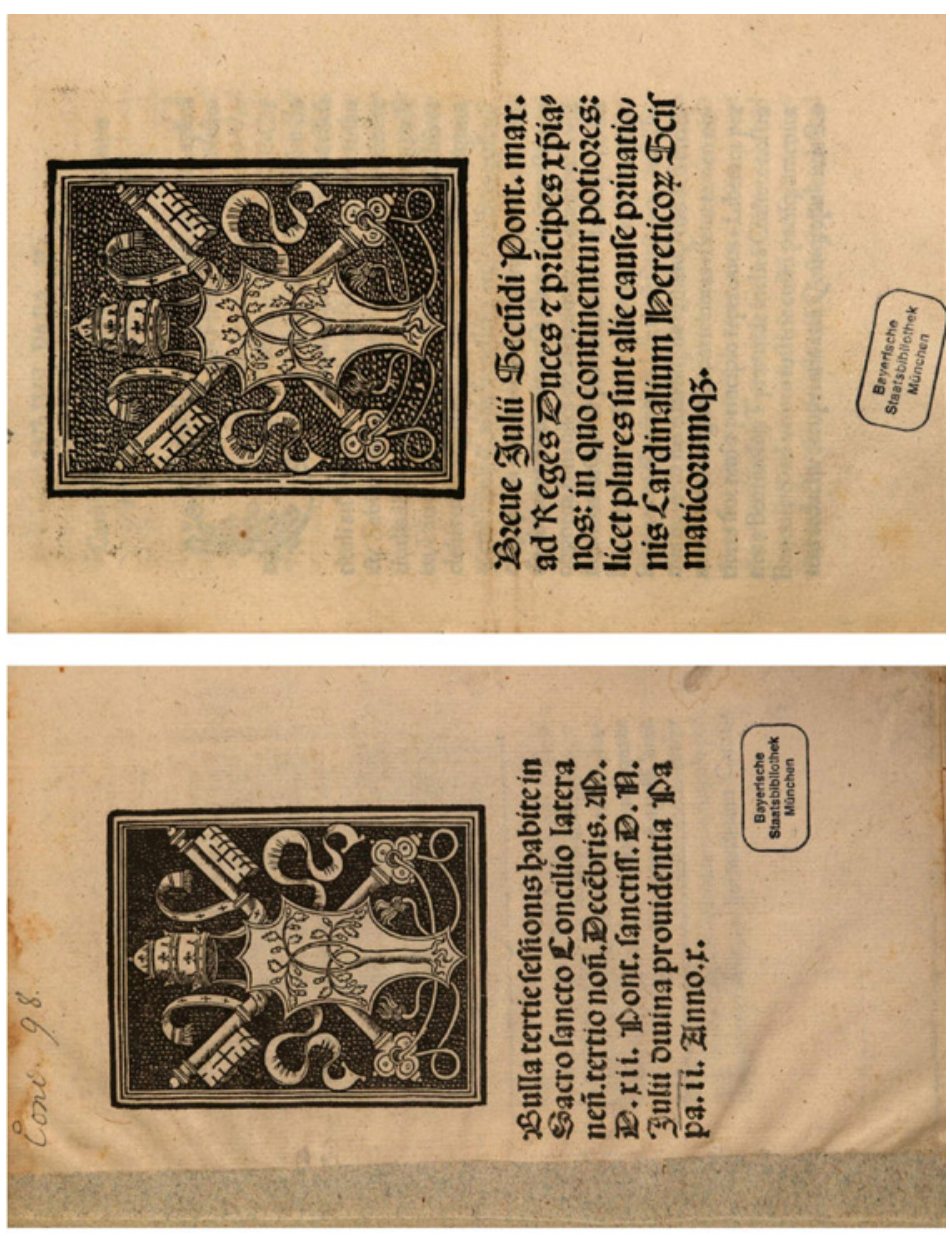

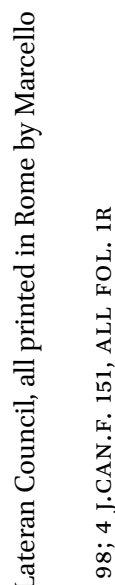

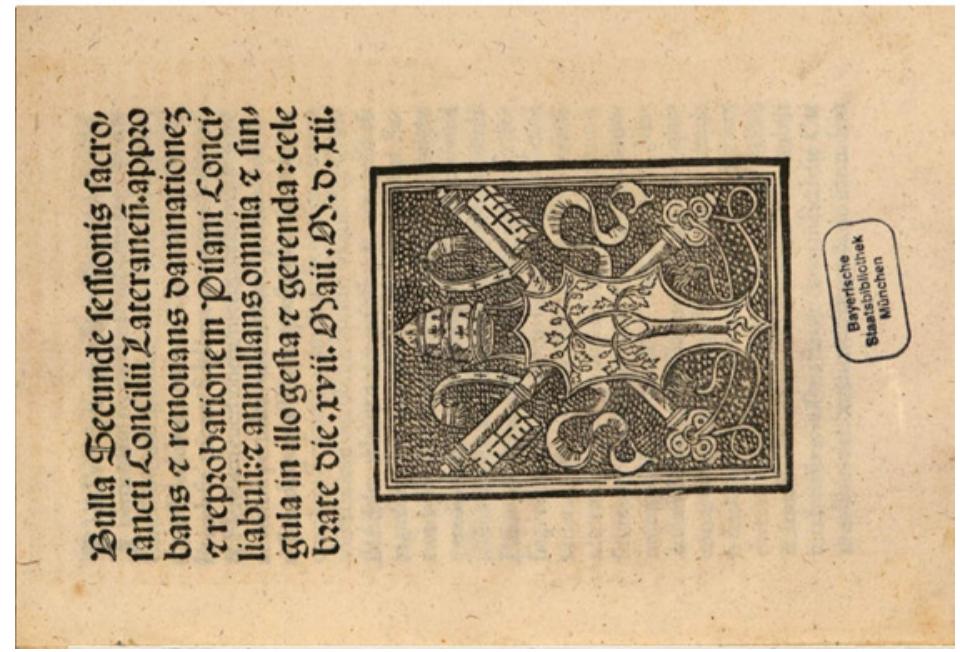

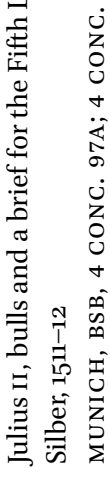

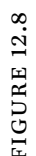


commonplace since the popes returned to Rome from Avignon and resumed the government of the papal states. What was new, once again, was the format. Julius saw his administrative bulls published in quarto, with title pages bearing the Julian coat of arms and a title in larger type indicating the contents of the pamphlet: precisely the same format as his political bulls.

Julius' various rhetorical, legal, and presentational strategies reached their apex in the suite of fourteen different bulls, printed in 43 different editions, which he issued in connection with Lateran v. The Julian chancery published these over the last seventeen months of the pope's life, from his Bulla intimationis announcing the council on 18 July 1511 to the Cedula quintae sessionis published on 16 February 1513, just five days before Julius' death. ${ }^{51}$

Julian bulls proclaiming the council, attacking and excommunicating opponents of the council, and publicizing the work of the council (from positive reform measures to yet more sanctions against political opponents), appeared in print alongside dozens of other editions of orations, sermons, and speeches delivered by clerics at the Council. Several Roman printers produced series of these bulls, although Marcello Silber seems to have been the most frequent and possibly the original publisher; each used his own consistent visual and textual apparatus. These collections of printed texts carried the deliberations and the very fact of the council far beyond its meeting rooms at the Lateran, underscoring its legitimacy and superiority over any rival assembly.

\section{Conclusion}

The length of Julian bulls, the innovations in their visual presentation, and the multiplying types of document that were put into print all suggest how innovative the Julian papal chancery, and the printers it contracted with, could be in their use of the new technology. Printing changed the way bulls read, how they looked, and how they were used, as they increasingly were directed not just against other political actors but also to the court of public opinion. In this sense, we might say print functioned here in a truly "revolutionary" way or at least, that the Julian chancery was revolutionary in the way it used the technology to transform both the content and the form of a highly traditional medieval document.

And yet, if we consider the message conveyed by Julian publicity campaigns, they still had at their heart a highly traditional, even retrograde vision of the church, its leadership, and their relationship to the faithful. Julius 
flooded Europe with printed publications that insisted on the ecclesiology of previous centuries, based on the principles of papal supremacy over cardinals and temporal princes, on the one hand, and salvation by works (specifically, the purchase of indulgences), on the other. Subsidiary concerns included the defeat of the infidel, the pope's absolute authority over his vassals in the papal states, and the subordination of the council to the pope. These were the ideas that papal print broadcast to the European reading public at the start of the sixteenth century. Even Lateran v, ostensibly convened to reform the church in head and members, was more immediately motivated by Julius' desire to quash the French king's challenge to his authority and his rival council at Pisa. The Lateran documents that were printed focused on process: on the need for every cardinal to adhere to Julius' council; on the pope's precedence over secular rulers; and on his exclusive right to call a council in the first place and to condemn rival assemblies.

Lateran $\mathrm{V}$ continued after Julius' death; Leo $\mathrm{x}$ presided over another four years of meetings, with many more decrees and declarations printed, now in pamphlets bearing the familiar arms of the Medici pope. The council closed just seven months before Luther released his 95 theses to the public. The story of that document's publication lies beyond the scope of this study, but it is worth remembering that in 1520, when Leo issued the bull Exsurge domine condemning the German theologian, the text quickly appeared as a quarto pamphlet from a Roman press, with an explanatory title and the pope's coat of arms; it was copied by other printers and released in multiple editions across northern Europe. ${ }^{52}$ Luther, on receiving his copy, threw it on the fire.

The Reformers' use of the press would soon outstrip that of the papacy's. Lutheran propaganda was more varied and versatile; it drew on vernacular narrative traditions and potent visual vocabularies; above all, it touched on genuine concerns among the European faithful that papal propaganda had failed to address over the previous fifty years. The popes had printed dozens of papal bulls declaring their supremacy in matters both spiritual and temporal; their critics would broadcast attacks on these same claims and practices, using the same medium, to devastating effect. There can be no doubt that the papacy used the press, often in innovative ways, years and even decades before the Reformation. But the constraints of their own ecclesiology kept them from using the new technology in any but the most traditional ways.

52 Leo X, Bulla contra errores Martini Lutheri et sequacium (Rome: Giacomo Mazzocchi, 1520), Ustc 837884. Reprinted at least eleven times by printers in Paris, Leipzig, Erfurt, Cologne, Rostock, Strassburg, Antwerp, and Landshut: see entries in USTC under the title Bulla contra errores. 


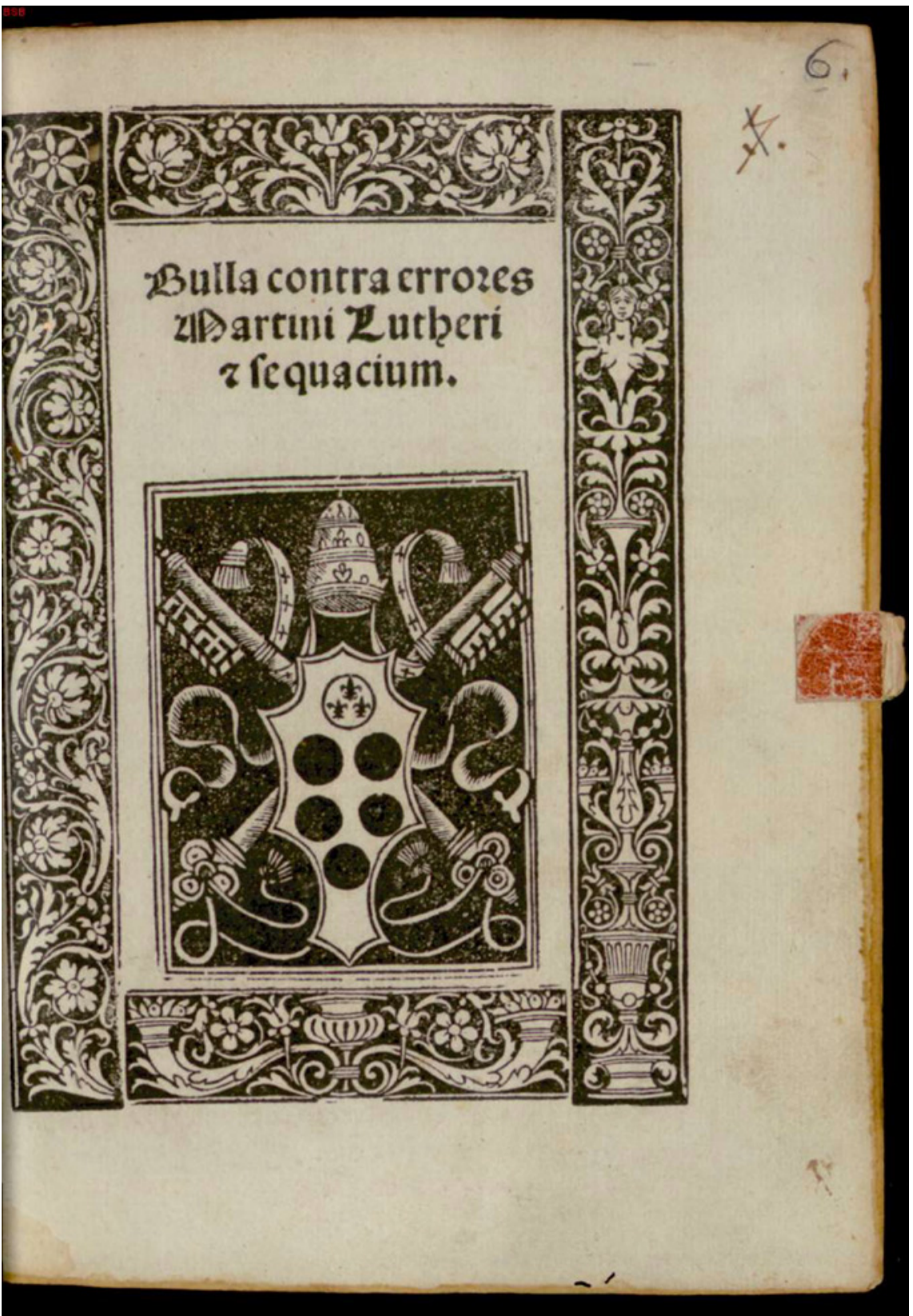

FIGURE 12.9 Leo X, Bulla contra errores Martini Lutheri et sequacium [Rome, 1520] MUNICH, BSB, RAR. 1477\#BEIBD.6, FOL. 1R 


\title{
Appendix: Printed Political Bulls of Pope Julius II
}

\author{
Abbreviations \\ BAV Biblioteca Apostolica Vaticana \\ B L British Library in London \\ BSB Bayerische Staatsbibliothek in Munich \\ Casanatense Biblioteca Casanatense in Rome \\ Roma N Biblioteca Nazionale Centrale di Roma
}

\section{Bulls against Bologna, Venice, Ferrara \\ 1.1 BUll AgAinst giovanni Bentivoglio (1o October 15o6) ${ }^{53}$}

Bulla Iulii Pape ii edita contra Johannem Bentivolum in civitate Bononiensi libertatem ecclesiasticam occupantem

a) Rome: Johannes Besicken, 12 November 1506. 6 leaves

Inspected copies: BAV R.I.IV.961(2); R.I.IV.1414(9); Casanatense Misc. Rara 79;

Roma N Misc. Val. 1875.31(6).

EDIT-16 43484, USTC 762404

b) Rome: Johannes Beplin de Argentorato, 12 November 1506.546 leaves

Inspected copies: BAV R.I.IV.1811(24); BAV Stamp.Ross.4315 (int. 2); Roma N Misc.

Val. $1875 \cdot 31(7)$.

EDIT-16 54241, USTC 762651

1.2

BULL IN CENA DOMINI (20 April 1508)

Bulla in cena Domini

a) [Rome: Eucharius Silber, 1508]. 4 leaves

Inspected copies: BAV R.I.IV.1811(12b); Stamp.Ross.4222(1); Roma N 1875.31(10)

EDIT-16 51370, USTC 762561

b) [Rome: Etienne Guillery, 1508]. 4 leaves

Inspected copies: BAV Stamp.Ross.4222(2); Casanatense, Misc. Rara 26 (var)

EDIT-16 51254, USTC 762555

53 Neither edition provides the date for the bull, for which see Pastor, History of the Popes, 6.277.

54 This edition is signed 12 November 1506 but both the type and the woodcut deployed are not found in Beplin editions again until 1510, suggesting this may be a falsely dated reprint of Besicken's edition, printed later in Julius' reign. 


\subsection{Bull of WARning Against venice (27 April 1509)}

Monitorium contra Venetos

a) Rome: Giacomo Mazzocchi, [1509]. 12 leaves

Inspected copies: BAV R.I.IV.1414(8); Roma N 1875.31(12)

EDIT-16 51232, USTC $76255^{\circ}$

b) Rome: Giacomo Mazzocchi, [1509]. 12 leaves

Inspected copy: BAV R.I.IV.2121(2)

EDIT-16 51230, USTC 762549

c) Rome: Giacomo Mazzocchi, [1509]. 12 leaves

Inspected copy: Bologna Biblioteca Universitaria A.5.Tab.1.I.2.73/3

EDIT-16 54240, USTC 76265 Oa

d) Rome: Giacomo Mazzocchi, [1509]. 10 leaves

Inspected copies: Bs в Res/4 Eur. 330.23; BL 697.e.34

EDIT-16 7750O, USTC 765068

e) [Rome, Eucharius Silber, 1509]. 8 leaves

Inspected copies: BAV Stamp. Ross. 4312(1); BSB J.can.f. 176

EDIT-16 54421, USTC 762662

f) [Rome, Eucharius Silber, 1509]. 8 leaves

Inspected copies: BAV R.I.IV.961(3); Roma N 1875.31(11)

EDIT-16 43489, USTC 762407

g) [Nuremberg, Georg Stuchs, 1509]. 10 leaves

Inspected copies: BSB, J.can.f. 276.7; Res/4 A.gr.b. 1150

VD16 zV 23163, USTC 676387

h) Leipzig: Martin Landsberg, 1509. 10 leaves

Inspected copy: Halle, Universitäts- und Landesbibliothek Sachsen-Anhalt vD16 K 25o, UsTC 676386

Bebstliche vermanung widder die Venediger

i) Leipzig: Martin Landsberg, 1509. 16 leaves

Inspected copy: BSB J.can.f. $244 \mathrm{~b}$

VD16 K 253, USTC 615400 
Die paepstlich büll, proceß, bann unnd anathema so unnser allerhailigister vatter Pabst Julius, wider das groß commun der Venediger

j) [Augsburg: Johann Otmar, 1509]. 10 leaves

Inspected copy: BSв Rar. 148

VD16 K 252, USTC 637011

k) [Augsburg: Johann Otmar, 1509]. 10 leaves

Inspected copy: BSB 2.J. can. F. 141

VD16 K 251, USTC 637012

La monicion, excommuniment, anathematisation et malediction contre les Veniciens

l) Lyon: Noël Abraham, [15o9]. 8 leaves?

UsTC 6498 o

m) [Paris: Michel Le Noir], 1509. 8 leaves

USTC 64981

\section{Admonitione contra li Venetiani}

n) [Ferrara?, s.n., 1509]. 8 leaves

Inspected copy: BL 8o32.d.52

EDIT-16 43487, USTC 762406

\subsection{BULL STRIPPING ALFONSO D'ESTE OF HIS DUKEDOM (9 August 1510)}

Bulla Iulii II. Pont. Max. super privatione Alfonsi ducis Ferrariae

a) Rome:Jacobus Mazochius, 1510. 16 leaves.

Inspected copies: BAV R.I.IV.961(4); R.I.IV.1414.(6); R.I.IV 2121(3); Roma N 1875.31(14)

EDIT-16 43492, USTC 762409

b) [Rome: s.n., 1510]. 10 leaves.

Inspected copy: BSB 4.J.can.f.158

EDIT-16 54129, USTC 762639

c) Bologna, s.n., 1510.8 leaves

Inspected copy: Biblioteca Nazionale Centrale di Firenze

EDIT-16 54038, USTC 762636 
d) Venice: Franciscus Lucensis, [1510]. 10 leaves.

Inspected copy: BAV R.I.IV.1811(20)

EDIT-16 75196, USTC 763321

Summario dela scomunicha de Ferrara

e) [Rome?: s.n., 1510]. 4 leaves.

EDIT-16 71957, USTC 763117

\subsection{BULL OF INTERDict AGAINST MILAN (9 October 1510)}

Bulla censurarum in singulos de consilio et interdictigeneralis in ducatu mediolanensi ob occupationem ecclesiarum et aliorum beneficiorum ecclesiasticorum, et fructuum eorundem indebitam sequestrationem, seu distributionem, laicali abusu e potentia factas

a) [Rome: Marcello Silber, 1510]. 6 leaves.

Inspected copies: BAV R.I.IV.961(6); Casanatense Vol. Misc. 2059.14(14) (var)

EDIT-16 75197, USTC 763322

b) [Rome: Marcello Silber, 1510]. 4 leaves.

Inspected copies: BAV R.I.IV.1811 (23); Roma N 1875.31(15).

EDIT-16 51272, USTC 762557

c) [Rome? s.n., 1510]. 4 leaves.

EDIT-16 76404, USTC 764261

d) [Rome, Eucharius Silber?, 1510]. 6 leaves.

Inspected copy: BL 697.f.39.

EDIT-16 764O5, USTC 764262

e) Leipzig, Martin Landsberg, [1510]. 6 leaves.

Inspected copies: Halle, Universitäts- und Landesbibliothek Sachsen-Anhalt;

Regensburg, Staatliche Bibliothek, G/68/480

VD16 K 239, USTC 617357

1.6

$$
\begin{aligned}
& \text { BULL AGAINST ALFONSO D'ESTE, CHARLES D'AMBOISE, AND } \\
& \text { THE CAPTAINS OF FRENCH ARMY (14 October 1510) }
\end{aligned}
$$

Bulla declarationis incursus censurarum et penarum contentarum in bulla privationis Alphonsi Estensis tunc ducis Ferrariae, contra Magnificum dominum Carolum de Ambosia de Ciamonte magnum magistrum et nominatim contra reliquos capitaneos et 
duces exercitus Christianissimi regis Francorum, et generaliter contra omnes qui in defensionem et auxilium dicti Alphonsi Estensi contra S. D. N. et sanctam Romanam ecclesiam militant, et eius terras et loca hostiliter invaserunt, et depredati sunt.

a) [Rome, Marcello Silber, 1510]. 6 leaves.

Inspected copies: BAV. R.I.IV.961(5); Stamp.Ross.4314(1) (var); R.I.IV.1811(21) (var); Casanatense, Vol. Misc. 2059.14(15) (var)

EDIT-16 43491, USTC 762408

b) [Rome: Marcello Silber, 1510]. 4 leaves

Inspected copies: BAV R.I.IV.1414(7); R.I.IV.1811(22); Roma N 1875.31(16)

EDIT-16 51276, USTC 762559

c) [Rome: Etienne Guillery, 1510]. 4 leaves

Inspected copy: BAV Stamp.Ross.4315(3)

EDIT-16 51371, USTC 762562

d) Venice: Franciscus Lucensis, 15 November 1510. 4 leaves.

Copies: BAV R.I.IV.1681(8), BL 1481.aaa.27.

Not in EDIT-16 nor in USTC

e) Leipzig: Martin Landsberg, [1510]. 6 leaves.

Inspected copy: Halle, Universitäts- und Landesbibliothek Sachsen-Anhalt

VD16 zV 21528, USTC 617365

\section{(4 November 1510)}

Bulla interdicti ecclesiastici contra receptatores rebelium et exititiorum terrarum Ecclesie infra quinquaginta miliaria a locis originis illorum distantibus per S. D. N. Iulium II. pont. max. edita.

a) [Rome, Marcello Silber? 1510]. 4 leaves.

Inspected copies: BAV R.I.IV.1681(6); R.I.IV.1811(19)

EDIT-16 75195, USTC 763320

1.8

BULL RENEWING “EXECRABILIS” (1 July 1509)

Bulla innovans et confirmans constitutionem sive extravagantem Pii II contra appellantes ad futurum Concilium per s. dominum nostrum Iulium II Pont. Max. edita. 
a) [Rome?: s.n., after 17 December 1510$].{ }^{55} 4$ leaves.

Inspected copies: s: BAV R.I.IV.1811(14); R.I.IV.961(8); Roma N 1875.31(13)

EDIT-16 51814, USTC 763320

b) [Rome?: s.n., after 17 December 1510]. 6 leaves.

Copy: вSB 4J.can.f.166

Not in EDIT-16 nor in USTC

1.9 BULL IN CENA DOMINI (17 April 1511)

Bulla lecta in cena Domini continens multorum excommunicationes, suspensiones \&c. per s. d. n. Iulium II pont. Max. edita et in calce eiusdem bulle executio.

a) [Rome or Bologna? : s.n., 1511]. 6 leaves.

Inspected copy: Roma $\mathrm{N}$

EDIT-16 54211, USTC 836658

$2 \quad$ Bulls Against the Pisan Council

2.1 BULL ANNOUNCING THE FIFTH LATERAN COUNCIL (18 July 1511)

Bulla intimationis generalis concilii apud Lateranum per s. d. n. Julium Papam II. edita

a) Rome: Giacomo Mazzocchi, 31 July [1511]. 10 leaves.

Inspected copies: BAV R.I.IV 2107(1); Roma N 1875.31(18) (var)

EDIT-16 13918, USTC 837537

b) Rome: Giacomo Mazzocchi, [1511]. 10 leaves.

Inspected copy: Roma $\mathrm{N}$

EDIT-16 52714, USTC 837535

c) [Rome: Etienne Guillery?, 1511]. 8 leaves.

Inspected copy: Casanatense Misc. Rara 24

EDIT-16 13917 (= 54246), USTC $837540(=837534)^{56}$

55 Includes notes on the circulation and public display of the document, the latest dated 17 December 1510.

$5^{6}$ Both in EDIT-16 and UstC the two different records refer to the same edition. 
d) [Rome: s.n., 1511]. 10 leaves

Inspected copies: Roma N, Bologna Biblioteca Universitaria EDIT-16 51298, USTC 837538

e) [Rome: s.n., 1511]. 8 leaves

Inspected copy: Pavia Biblioteca Universitaria

EDIT-16 77489, USTC 765058

f) [Rome: s.n., 1511]. 6 leaves

Inspected copy: Roma $\mathrm{N}$

EDIT-16 59O54, USTC 837536

g) Bologna: Benedictus Hectoris, 25 August 1511.10 leaves. Inspected copy: Bologna Comunale dell'Archiginnasio

EDIT-16 13915, USTC 837529

h) Venice: Gregorius de Gregoriis, [1511]. 8 leaves.

Inspected copy: BL 697.f.37

EDIT-16 13919, USTC 837539

i) Leipzig: Martin Landsberg, 1511. 10 leaves

Inspected copy: Berlin Staatsbibliothek

VD16 K 241, USTC 617371

j) [Nuremberg: Johann Weissenburger, 1511]. ${ }^{57} 8$ leaves

Inspected copies: BAV Inc. V.11o (6) (olim R.I.V. 1344); R.I.IV.2116(4); BAV R.I.IV.1803(4) (var)

VD16 K 242, USTC 617369

k) Burgos: Fadrique de Basilea, 1511.

USTC 347569

Bolla de la notitia del concilio de Roma a Santo Joane Laterano, fata per el santissimo signor nostroJulio papa secundo.

57 This is a composite volume of seven Julian bulls having to do with the Pisan and Lateran councils, signed A- $\mathrm{G}^{4}, \mathrm{Aa}^{4}$ with the printer's colophon on sig. Aa4 ${ }^{\mathrm{v}}$. The Bulla intimationis occupies quires A-B. Each subsequent bull fills a separate quire, and as they are more frequently found (and catalogued) separately than bound together, I list them as separate editions here. 
l) Venice: s.n., after 4 October $1511 .^{58} 8$ leaves.

Inspected copy: BAV R.I.IV 2107(2)

EDIT-16 13916, USTC 837533

Bulla der aussatzunge und verküdunge eins gemeynen concilii; so tzu Rhom in Sant Johan Lateran kirchen sall gehalten werden, durch unsern heyligisten vater Julium Babst den andern gemacht und ausgangen.

m) Leipzig: Martin Landsberg, 1512. 10 leaves

Inspected copy: Leipzig, Universitätsbibliothek

VD16 ZV 15992, USTC 617366

n) Leipzig: Martin Landsberg, 1512. 8 leaves

Inspected copy: Zwickau, Ratschulbibliothek

VD16 zV 8856, USTC 617367

2.2

\section{BULL WARNING THREE CARDINALS TO RETURN TO OBEDIENCE (28 July 1511)}

Bulla monitorii apostolici contra tres reverendissimos cardinales ut redeant ad obedientiam S.D.N. pape ne scisma in ecclesia sancta dei oriatur

a) [Rome: Giacomo Mazzocchi or Etienne Guillery, 1511]. 8 leaves Inspected copies: BAV R.I.IV.961(8b); Casanatense Vol. Misc. 2059.14(16); Roma N 1875.31(19); BS B 4J.can.f 161 (var) EDIT-16 51234, USTC 836659

b) [Rome: Marcello Silber, 1511]. 4 leaves

Inspected copies: BAV Stamp.Ross.4312(2); BSB 4 J.can.f. 162; BAV R.I.IV.1414(2) (var). ${ }^{59}$

EDIT-16 51283, USTC 83661

c) [Rome? s.n., 1511]. 4 leaves

Inspected copy: Parma, Biblioteca Palatina

EDIT-16 78982, not in USTC

$5^{8}$ EDIT-16 attributes this to Mazzocchi but the Venetian printer has copied the colophon from an earlier Mazzocchi edition. On fol. 8v is printed "concessa benigna licentia dal reverendissimo monsignor legato apostolico in Venesia. M.cccccxi. a di iiii. otobrio."

59 Woodcut stemma very similar, possibly identical, to that used in 1.1.b above, an edition signed by Beplin. 
d) [Nuremberg:Johann Weissenburger, 1511]. 4 leaves

Inspected copies: BAV Incun.V.11O(11) (olim R.I.V.1344); Regensburg, Staatliche Bibliothek 999/Patr.544k(2)

Not in VD-16 nor in USTC. ${ }^{60}$

e) [Nuremberg:Johann Weissenburger, 1511]. 6 leaves

Inspected copy: Regensburg, Staatliche Bibliothek B 999/Patr.544k(3)

Not in VD-16 nor in USTC. ${ }^{61}$

\subsection{BUll of PRivation AgAinst René de PRE (24 October 1511)}

Bulla super sententia privationis Renati de Pria, olim Card. S.R.E. Bayocensis per S.D.N. facte in consistorio publico ad futuram rei memoriam

a) [Rome: Etienne Guillery?, 1511]. 12 leaves

Inspected copies: BAV Stamp.Ross.4312(3); R.I.IV.1414(5); Casanatense Misc Rara 23; Roma N 1875.31(24)

EDIT-16 506o9, USTC 836665

2.4

BULL OF PRIVATION AgAINST THE THREE CARDINALS

(24 October 1511)

Bulla super sententia privationis in publico consistorio facte per S.D.N. contra D. Bernardum Carvaialem, Guillermum Brizonettum et Franciscum de Borgia olim S.R.E. cardinales ad futuram rei memoriam

a) [Rome: Etienne Guillery? 1511]. 12 leaves

Inspected copies: BAV Stamp.Ross.4312(4); R.I.IV.1414(1); Roma N 1875.31(23)

EDIT-16 51375, USTC 836664

b) [Rome: Etienne Guillery?, 1511]. 12 leaves

Inspected copies: BAV R.I.IV.961(9b); Roma N 1875.31(22); Casanatense Misc. Rara 22

Not in EDIT-16 nor in USTC

6o This edition is signed $\mathrm{C}^{4}$ and is likely part of the composite Weissenburger edition described in 2.1.j above. Facsimile at https://reader.digitale-sammlungen.de/de/fsi/ object/display/bsb1130189o_oooo2.html.

61 This edition, by the same printer as the previous (almost certainly Weissenburger), is signed $\mathrm{A}^{6}$ and is unquestionably an independent edition: https://reader.digitale-sammlungen. de/resolve/display/bsbi13o1895.html. 
Breve ad reges duces et principes christianos in quo continentur potiores (licet plures sint alie) causae privationis cardinalium hereticorum scismatorumque

a) [Rome:] Giacomo Mazzocchi, on or after 25 October $1511 .{ }^{62} 4$ leaves Inspected copies: BAV, R.I.IV.1414(3); R.I.IV.961(9); R.I.IV.1811(15); Roma N $1875 \cdot 31(20)$

EDIT-16 51235, USTC 836655

b) [Rome: Giacomo Mazzocchi, 1511]. 2 leaves

Inspected copy: Roma N 1875.31 (21)

EDIT-16 51237, USTC 836657

c) [Rome: Etienne Guillery, 1511]. 2 leaves

Inspected copies: Casanatense Misc. Rara 55; BS B 4 J.can.f. $15^{2}$.

EDIT-16 43495, USTC 836656

d) [Nuremberg: Johann Weissenburger, 1511]. 4 leaves. ${ }^{63}$

Inspected copies: Copies: BAV R.I.IV. 2116(3); Inc. V. 110(12) (olim R.I.V.1344)

Not in VD16 nor in USTC.

2.6

BULL OF WARNING TO BISHOPS OF FRANCE PARTICIPATING

IN THE COUNCIL OF PISA (3 December 1511)

Bulla monitorii et declarationis incursus privationis et aliarum penarum contra prelatos gallice nationis hic expressos, qui intervenerunt in pisano conciliabulo cum scismaticis.

a) [Rome: Johannes Beplin or Marcello Silber?, 1511]. 6 leaves

Inspected copies: BAV R.I.IV.961(10); Roma N 1875.31(25); BSB 4. Conc. 142 (var)

EDIT-16 $51317(=43497)$, USTC $836662(=83663)^{64}$

62 Fol. 4v: "Nullus hoc Breve imprimere audeat nisi post diem Octava a kalendis Novembris computandam, sine licentia secretarii nostri domestici Sigismundi. De mandato prefati Magnifici domini Secretarii impressi ego Iacobus de Mazochis."

63 Signed $\mathrm{F}^{4}$. Likely part of the composite Weissenburger edition described in 1.10.j above.

64 Both in EDIT-16 and USTC the two different records refer to the same edition. 
Bulla ultima convocationis et invitationis cardinalium absentium et prelatorum gallice nationis, ad celebrationem concilii Lateranensis cum declaratione nullitatis gestorum per conciliabulum pisanum per s.d.n. Iulium II pontificem maximum edita

a) [Rome: Johannes Beplin? 1512]. 4 leaves.

Inspected copies: BAV R.I.IV.1414(10); Roma N 1875.31(30) (var)

EDIT-16 13928, USTC 837554

b) [Rome: Marcello Silber? 1512]. 4 leaves

Inspected copy: Rome, Biblioteca dell' Accademia Nazionale dei Lincei e Corsiniana

EDIT-16 13929, USTC 837555

c) [Rome?: s.n., 1512]. 4 leaves

Inspected copies: Roma N, Bologna Biblioteca Universitaria

EDIT-16 51299, USTC $83755^{6}$

d) [Nuremberg?: Johann Weissenburger? 1512]. 4 leaves

Inspected copy: BSB 4 Conc. 102

VD16 K 249, USTC 617382

\section{Bulls of Lateran $\mathrm{V}$}

3.1 BULL POSTPONING THE OPENING OF THE COUNCIL

(17 April 1512)

Bulla prorogationis generalis concilii apud Lateranum

a) [Rome: Giacomo Mazzocchi or Etienne Guillery?, 1512]. 2 leaves

Inspected copies: BAV R.I.IV.2107(5); Roma N 1875.31(33)

EDIT-16 13920 (= 51381), USTC $837543(=837542)^{65}$

65 Both in EDIT-16 and USTC the two different records refer to the same edition. 
Bulla secunda sessionum in sacrosanctum concilii Lateran. approbans et renovans damnationem et reprobationem Pisani conciliabuli, et annulans omnia et singula in illo gesta et gerenda

a) [Rome: Marcello Silber, 1512]. 4 leaves

Inspected copies: BAV R.I.IV.961(11b); Roma N 1875.31(34)

EDIT-16 13923, USTC 837548

b) [Rome: Marcello Silber, 1512] 4 leaves

Inspected copy: BAV R.I.IV 2107(9)

EDIT-16 13925, USTC 837547

c) [Rome: Marcello Silber, 1512]. 4 leaves

Inspected copy: $\mathrm{BL}$

EDIT-16 65992, USTC $83755^{\circ}$

d) [Rome: Marcello Silber, 1512]. 4 leaves

Inspected copy: Biblioteca dell' Accademia Nazionale dei Lincei e Corsiniana EDIT-16 13924, USTC 837549

\section{$3 \cdot 3$}

\section{BULL OF INTERDiCT AgAinst FRANCE (13 August 1512)}

Bulla interdicti generalis in universo regno Francie et translationis nundinarum ex Lugduno ad civitatem Gebenensem ex causis in bulla contentis

a) [Rome: Johannes Beplin?, 1512]. 4 leaves

Inspected copy: BSB 4 J.can.f. 163

EDIT-16 4350O, USC 836667

b) [Rome: Etienne Guillery?, 1512]. 4 leaves

Inspected copies: BAV R.I.IV.1414(4); BSB 4J.can.f. 164

Not in EDIT-16, USTC?

\subsection{BULL OF THE THIRD SESSION (3 December 1512)}

Bulla tertiae sessionis habite in sacro sancto concilio lateranensi tertio nonis decembris MDXII pontificis sanctissimi D.N. Julii divina providentia papa II anno X

a) [Rome: Marcello Silber, 1512]. 4 leaves

Inspected copy: BAV R.I.IV.2107(10)

EDIT-16 13927, USTC $83755^{2}$ 
b) [Rome: Marcello Silber?, 1512]. 4 leaves

Inspected copy: BAV R.I.IV.961(12)

Not in EDIT-16, nor in USTC

$3 \cdot 5$

BULL OF THE FOURTH SESSION (10 December 1512)

Bulla quarte sessionis habite in sacrosancto concilio Lateranensi quarto idus decembris MDXII pontificatus s.d.n. domini Julii divina providentia pape secundi anno decimo

a) [Rome: Marcello Silber? 1512]. 4 leaves

Inspected copy: BAV R.I.IV.961(12b).

EDIT-16 13921, USTC 837545

b) [Rome: Marcello Silber? 1512]. 4 leaves

Inspected copy: BAV R.I.IV.2107(13)

EDIT-16 13922, USTC 837544

3.6 DECREE ISSUED IN THE FIFTH SESSION (16 Feb. $1512(=1513)$ )

Julii secundi pontificis maximi decretum sanctissimum in quinta sessione sacri concilii Lateranensis de creatione summi pontificis approbatum

a) [Rome: Marcello Silber? 1513]. 6 leaves

Inspected copies: BAV R.I.IV. 2107(5); Stamp. Ferr. IV.8898(12); Roma N 1875.31(26) (var)

EDIT-16 13931 $(=13932=79204)$, USTC $83755^{8}(=8387559)^{66}$

$3 \cdot 7$

DOCUMENT ISSUED IN THE FIFTH SESSION CONCERNING

THE PRAgMATiC SANCTiON (16 Feb. 1512 (= 1513))

Cedula quintae sessionis prorogationis in causis reformationis et pragmatice sanctionis habite in sacrosancto concilio Lateranensi quartodecimo kalendis martiis MDXII pontificis sanctissimi domini nostri d. Julii secundi anno $X$

a) [Rome: Marcello Silber? 1513]

Inspected copy: BAV R.I.IV.2107(15)

EDIT-16 13930, USTC 837557

66 In EDIT-16 the three different records refer to the same edition, in USTC the two different records refer to the same edition. 